\title{
Geology, Ground-Water Occurrence, and \\ Estimated Well Yields from the Mariana \\ Limestone, Kagman Area, Saipan, \\ Commonwealth of the Northern Mariana Islands
}

U.S. GEOLOGICAL SURVEY

Water-Resources Investigations Report 98-4077

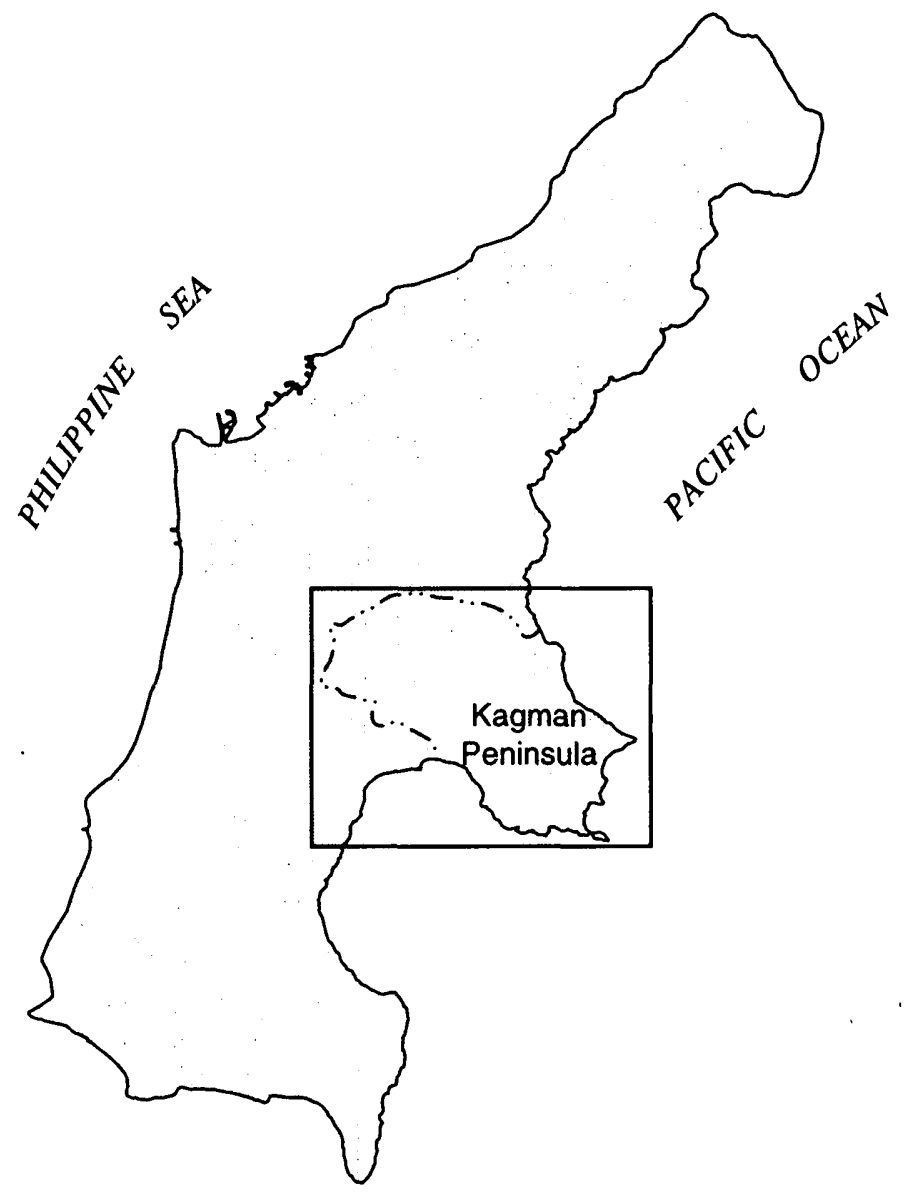

Prepared in cooperation with the

COMMONWEALTH OF THE NORTHERN MARIANA ISLANDS,

COMMONWEALTH UTILITIES CORPORATION, AND

DIVISION OF ENVIRONMENTAL QUALITY

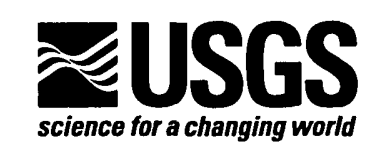





\section{Geology, Ground-Water Occurrence, and Estimated Well Yields from the Mariana Limestone, Kagman Area, Saipan, Commonwealth of the Northern Mariana Islands}

By John P. Hoffmann, Robert L. Carruth, and William Meyer

U.S. GEOLOGICAL SURVEY

Water-Resources Investigations Report 98-4077

Prepared in cooperation with the

COMMONWEALTH OF THE NORTHERN MARIANA ISLANDS, COMMONWEALTH UTILITIES CORPORATION, AND

DIVISION OF ENVIRONMENTAL QUALITY 


\section{U.S. DEPARTMENT OF THE INTERIOR BRUCE BABBITT, Secretary}

U.S. GEOLOGICAL SURVEY

Thomas J. Casadevall, Acting Director

The use of firm, trade, and brand names in this report is for identification purposes only and does not constitute endorsement by the U.S. Geological Survey.

For additional information write to:

District Chief

U.S. Geological Survey

677 Ala Moana Blvd., Suite 415

Honolulu, HI 96813
Copies of this report can be purchased from:

U.S. Geological Survey

Branch of Information Services

Box 25286

Denver CO 80225-0286 


\section{CONTENTS}

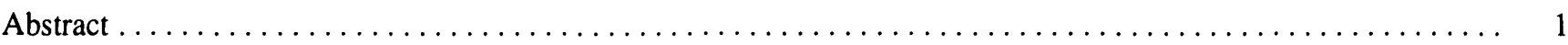

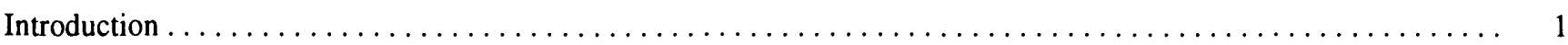

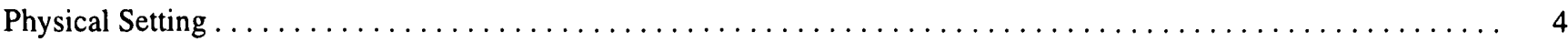

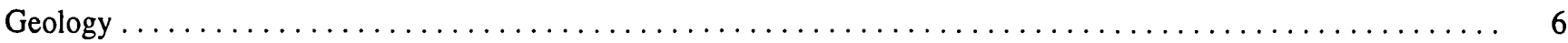

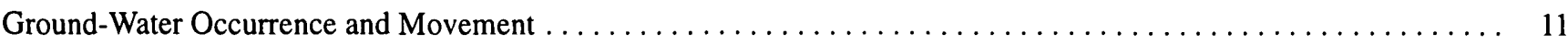

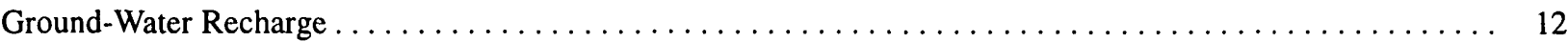

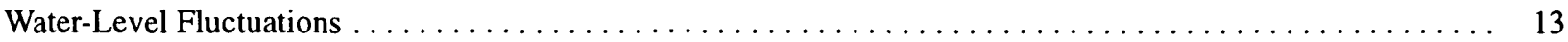

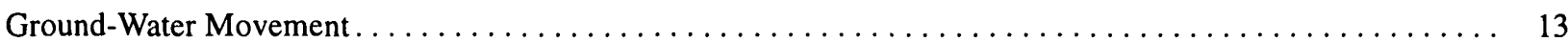

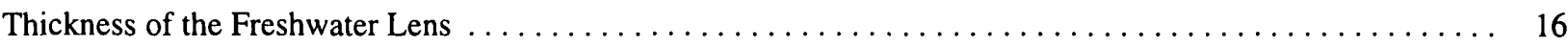

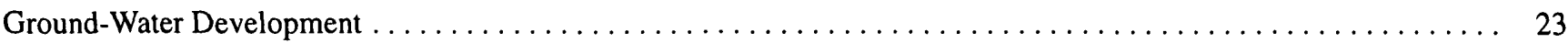

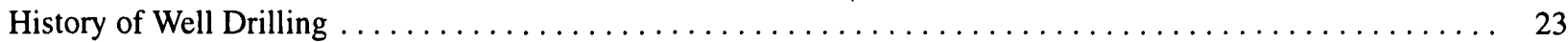

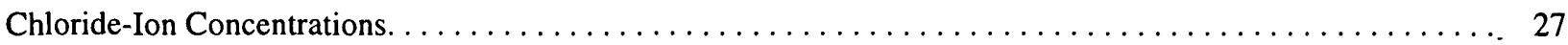

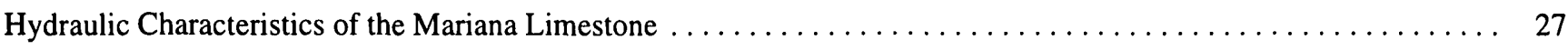

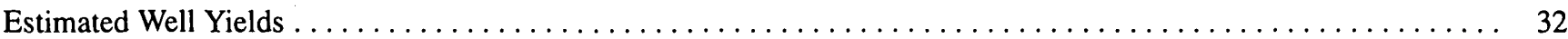

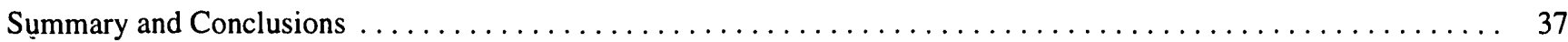

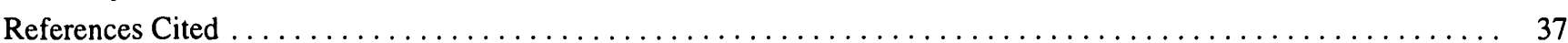

\section{FIGURES}

1-4. Maps showing:

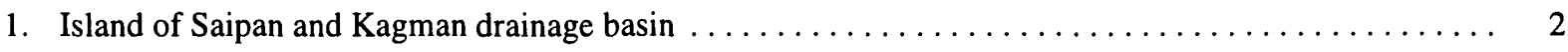

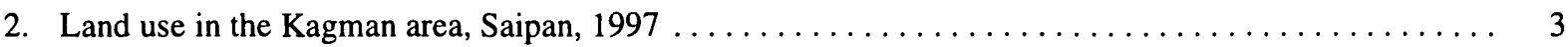

3. Test wells drilled in 1988 in the Kagman area, Saipan . . . . . . . . . . . . . . . . . . 5

4. Generalized surficial geology of the Kagman drainage basin, Saipan, and lines of geologic section . . . . 7

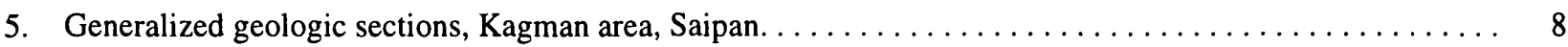

6. Idealized occurrence of fresh and saline ground water in an unconfined island aquifer $\ldots \ldots \ldots 11$

7. Hydrograph of water-level fluctuation at test well 13-T5, Kagman area, Saipan, and

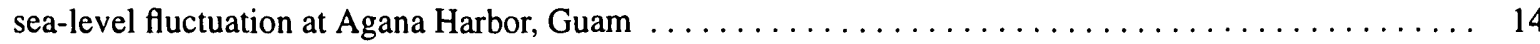

8. Generalized geohydrologic section showing occurrence and movement of fresh ground water in the Mariana and Tagpochau Limestones, Kagman area, Saipan . . . . . . . . . . . . . . 15

9-11. Maps showing:

9. Water-level altitude in test wells on January 22, 1989, beginning of dry season, Kagman area,

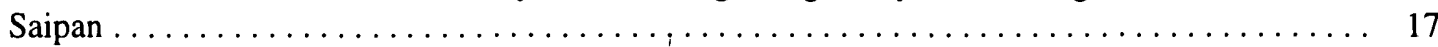

10. Water-level altitude in test wells on June 12, 1989, end of dry season, Kagman area, Saipan . . . . . . 18

11. Average altitude of water levels on September 7-14, 1989, middle of wet season, Kagman area,

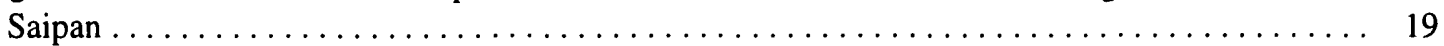

12. Thickness of freshwater lens, June 1989, and line of geohydrologic section, Kagman area, Saipan. . . . . . 20

13. Generalized geohydrologic section showing lines of equal percentage of seawater chlorideion concentration, Kagman area, Saipan, June $1989 \ldots \ldots \ldots \ldots \ldots \ldots \ldots \ldots \ldots \ldots$

14. Graphs showing chloride-ion concentration profiles in test wells, Kagman area, Saipan, June 2-5, 1989 
15-16. Maps showing:

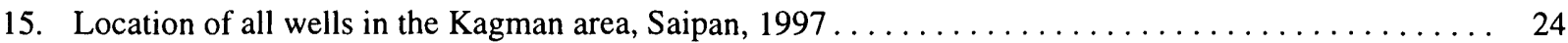

16. Production wells in operation in 1997, Kagman area, Saipan...................... 25

17-19. Graphs showing:

17. Chloride-ion concentration for well 13-03 (Ag. well) and rainfall, Kagman area, Saipan ........... 29

18. Water level in observation well 13-78 from January 1986 to June 1989, Kagman area, Saipan . . . . . . 30

19. Chloride-ion concentrations during pump tests (January 20-21, 1989) at selected production wells and test wells, Kagman area, Saipan. . . . . . . . . . . . . . . . . . . . . . . . 34

20. Upconing of the freshwater-saltwater interface beneath a pumping well $\ldots \ldots \ldots \ldots \ldots \ldots \ldots \ldots \ldots$

\section{TABLES}

1. Sea-level fluctuation and borehole water-level fluctuations for selected timespans, Kagman area, Saipan. ..... 13

2. Pumping rates and chloride-ion concentration for wells producing in the Kagman area, Saipan ........... 26

3. Chloride-ion concentrations for selected wells in the Kagman area, Saipan $\ldots \ldots \ldots \ldots \ldots \ldots \ldots \ldots \ldots \ldots$

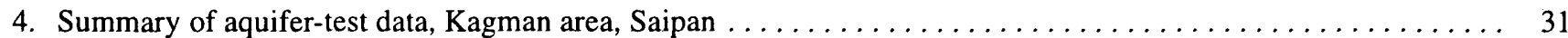

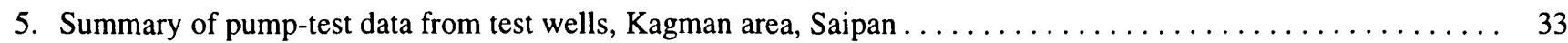

\section{Conversion Factors}

\begin{tabular}{rcl} 
Multiply & By & To obtain \\
acre & 4,047 & square meter \\
foot $(\mathrm{ft})$ & 0.3048 & meter \\
foot per day $(\mathrm{ft} / \mathrm{d})$ & 0.3048 & meter per day \\
square foot per day $(\mathrm{ft} / \mathrm{d})$ & 0.09290 & square meter per day \\
gallon $(\mathrm{gal})$ & 0.003785 & cubic meter \\
gallon per minute $(\mathrm{gal} / \mathrm{min})$ & 0.06308 & liter per second \\
gallon per minute per foot $(\mathrm{gal} / \mathrm{min} / \mathrm{ft})$ & 0.2070 & liter per second per meter \\
gallon per day $(\mathrm{gal} / \mathrm{d})$ & 0.06308 & liter per day \\
million gallons $(\mathrm{Mgal})$ & 3,785 & cubic meter \\
million gallons per day $(\mathrm{Mgal} / \mathrm{d})$ & 0.04381 & cubic meter per second \\
mile $(\mathrm{mi})$ & 1.609 & kilometer \\
square $\mathrm{mile}\left(\mathrm{mi}{ }^{2}\right)$ & 2.590 & square kilometer \\
inch $(\mathrm{in})$. & 25.4 & millimeter \\
inch per year $(\mathrm{in} / \mathrm{yr})$ & 2.54 & centimeter per year \\
\hline
\end{tabular}

\section{Abbreviation:}

$\mathrm{mg} / \mathrm{L}$, milligrams per liter

Temperature is given in degrees Fahrenheit $\left({ }^{\circ} \mathrm{F}\right)$, which can be converted to degrees Celsius $\left({ }^{\circ} \mathrm{C}\right)$ by using the equation:

$$
{ }^{\circ} \mathrm{C}=\left({ }^{\circ} \mathrm{F}-32\right) / 1.8
$$




\title{
Geology, Ground-Water Occurrence, and Estimated Well Yields from the Mariana Limestone, Kagman Area, Saipan, Commonwealth of the Northern Mariana Islands
}

\author{
By John P. Hoffmann, Robert L. Carruth, and William Meyer
}

\section{Abstract}

A study of the geology, ground-water occurrence, and estimated well yields from the Mariana Limestone was done to investigate ground-water availability in the Kagman area, Saipan. The Mariana and Tagpochau Limestone formations form the major aquifer in the Kagman drainage basin. The Mariana Limestone, which is the major waterbearing unit in the Kagman area, ranges in thickness from 300 to 500 feet and contains intermittent, thin clay stringers. The calcareous rocks of the Tagpochau Limestone range in thickness from 500 to 1,000 feet and are more sandy than those of the Mariana Limestone. Ground water is unconfined in the Mariana Limestone and ranges from unconfined to confined in the Tagpochau Limestone.

The fresh ground-water lens (that part of the lens with less than 2-percent of the chloride-ion concentration in seawater) in the Mariana Limestone is relatively thin, ranging from about 15 to 21 feet. Altitude of the water table ranges from about 1.5 to 2.5 feet above mean sea level. Freshwater in the Mariana Limestone is underlain by seawater and is separated by a transition zone about 8 to 25 feet thick. Hydraulic conductivity and transmissivity of the Mariana Limestone were calculated from data collected at six test wells. Using the Newman method, estimated hydraulic conductivity and transmissivity range from 290 to 2,500 feet per day and 7,600 to 62,000 feet squared per day, respectively. The higher values probably are indicative of average conditions in the Mariana Limestone. The estimated storage coefficient of the Mariana Limestone is about 0.1 .

The availability of water from the Mariana Limestone is restricted by the thinness of the freshwater lens. Results of the study indicate that fresh ground water can be obtained from the Mariana Limestone when wells are designed for minimum drawdown, effectively skimming freshwater from the top of the lens. Wells that are shallow, widely spaced, and pumped at low uniform rates can prevent saltwater intrusion. Calculated long-term yields of wells are about 30 gallons per minute or less for potable water.

\section{INTRODUCTION}

Saipan is the largest in the chain of 16 small islands that make up the Commonwealth of the Northern Mariana Islands (CNMI), a north-south trending chain in the tropical western Pacific (fig. 1). Saipan has an area of about $48 \mathrm{mi}^{2}$ and is elongated in the northeast-southwest direction. Mt. Tagpochau, the highest point on the island at $1,555 \mathrm{ft}$, is near the center of the island. Most of the island is more than $100 \mathrm{ft}$ above sea level and consists of a volcanic core overlain by younger limestones. With a population nearing 65,000 , Saipan is the center of government, transportation, commerce, and education for the CNMI.

The Kagman Peninsula (figs. 1 and 2), in the southeastern half of the Kagman drainage basin, is a relatively level limestone platform about $200 \mathrm{ft}$ above sea level (the name Kagman used in this report reflects the 

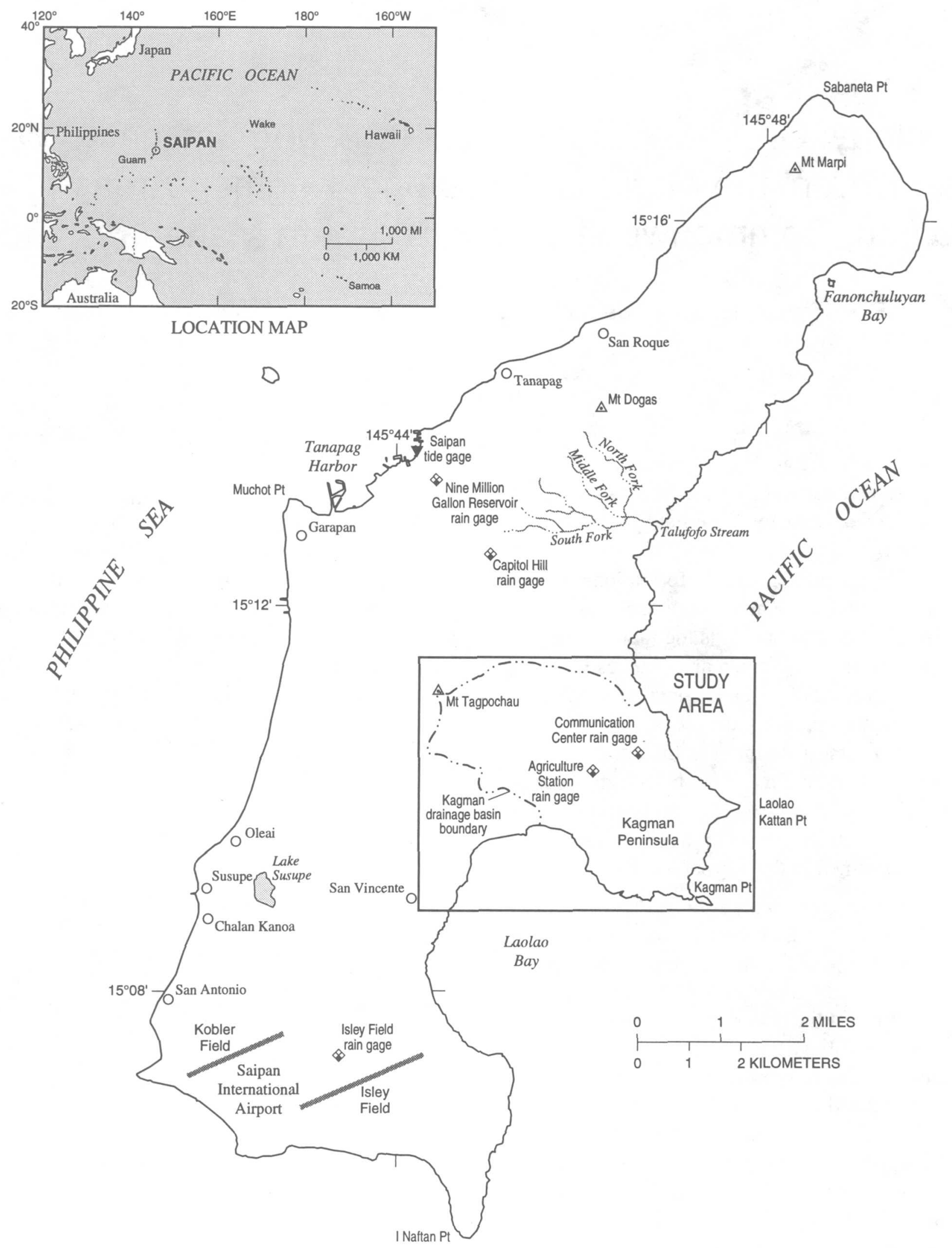

Figure 1. Island of Saipan and Kagman drainage basin. 


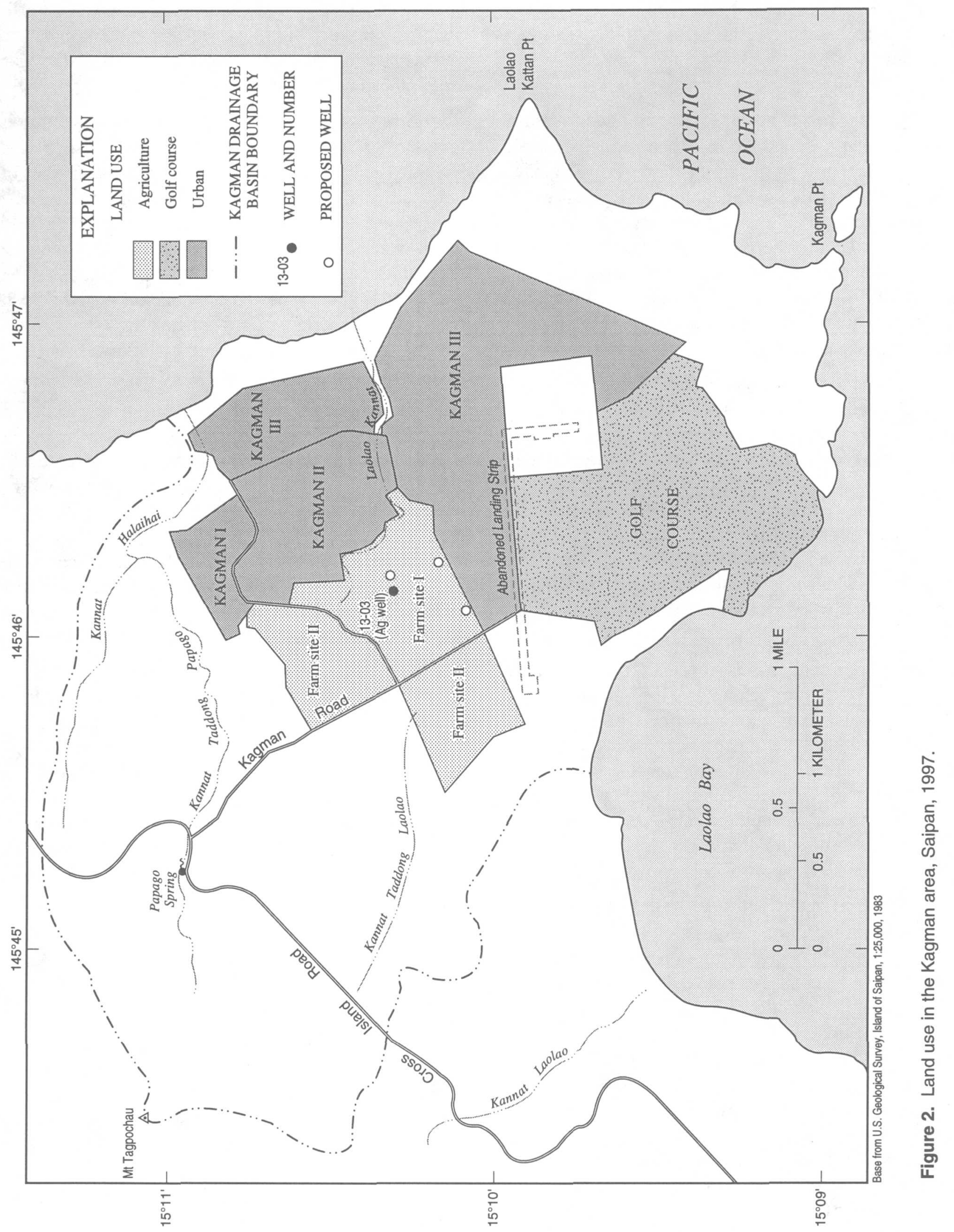


present pronunciation although various spellings exist for the name). A 40- to 50-in. clay soil overlies the peninsula and the area is well suited for farming and urban development.

The Kagman area has undergone rapid urban development in recent years. Three homestead subdivisions (Kagman I, II, and III) have been established on the peninsula (fig. 2). The latest subdivision, Kagman III, is the largest subdivision on the island and is made up of more than 1,800 lots in three phases. Municipal water demand could approach $1 \mathrm{Mgal} / \mathrm{d}$ in the near future (Commonwealth Utilities Corporation, personal commun, 1997). A 36-hole golf course development in the Kagman area (fig. 2) operates 14 on-site wells to provide an irrigation supply for the turfgrass areas.

Adjacent to the homestead subdivisions on the peninsula, about 146 acres of land are designated for agriculture by the CMNI government (fig. 2). About half of the 80 acres of Kagman Farm site I were under cultivation in 1997. One well on Farm site I provides water for irrigation during periods of low rainfall. The CNMI government is planning to cultivate the entire 80 acres of Farm site I and an additional 66 acres on Farm site II (fig. 2) which also will need a source of additional irrigation water when rainfall is low.

The U.S. Department of Agriculture, Natural Resources Conservation Service (NRCS) is cooperating with the CNMI government to provide a source of irrigation water and an irrigation distribution system for the Kagman Farm sites. The primary source of irrigation water will be a $70 \mathrm{Mgal}$ reservoir that captures stormwater runoff. Three additional wells will be constructed to provide a supplemental source of water during long periods of low rainfall (Charles Zuller, NRCS, oral commun., 1996).

In 1988, all municipal water wells operated by the Commonwealth Utilities Corporation (CUC) obtained water from the Tagpochau Limestone in the upper reaches of the Kagman Peninsula. The CUC is interested in obtaining additional fresh ground water from the Mariana Limestone in the central area of the peninsula to meet a growing municipal and agricultural demand, which may approach $2 \mathrm{Mgal} / \mathrm{d}$ in the near future (Commonwealth Utilities Corporation, personal commun, 1997). Because of the growing demand and to learn more about the ground-water system in the Kagman area, the NRCS, the CNMI Division of Environmental Quality (DEQ), the Commonwealth Utilities
Corporation, and the U.S. Geological Survey (USGS) began a cooperative study with the objective of describing the occurrence of ground water in the Kagman area and the possible yield from individual wells in the Mariana Limestone.

Purpose and Scope.--The purpose of this report is to describe the geology and occurrence of fresh ground water in the Kagman area, and to describe estimates of potential yield from wells in the Mariana Limestone. The occurrence of fresh ground water and potential well yields were determined by analysis of (1) the geology of the peninsula, (2) spatial and temporal variations of water levels in the limestone, (3) thickness of the freshwater lens, (4) inflow to and outflow from the aquifer system, (5) rates of ground-water withdrawal, and (6) hydraulic properties estimated from aquifer tests.

The study consisted of drilling eight test wells, 13T1, 13-T1b, 13-T2, 13-T2b, and 13-T3 through 13-T6 (fig. 3), to obtain information on geology, water levels, water quality, and hydraulic characteristics. Two test wells, 13-T1 and 13-T2, were later abandoned and replaced by test wells $13-\mathrm{T} 1 \mathrm{~b}$ and $13-\mathrm{T} 2 \mathrm{~b}$. The test wells were located to provide aerial coverage across the peninsula. Data from the test wells were combined with existing information on the geohydrology of the area to determine the feasibility of developing additional fresh ground water.

The test wells were drilled to depths ranging from about 10 to $36 \mathrm{ft}$ below mean sea level. Aquifer tests were done after which the wells were deepened to about $50 \mathrm{ft}$ below mean sea level in an attempt to penetrate the transition zone between the freshwater and saltwater. The test wells were capped and allowed to equilibrate for 5 months, after which water samples were collected at several depths from each well to obtain depth-salinity profiles. This information was used to map the extent of fresh ground water in the Kagman area.

\section{PHYSICAL SETTING}

The Kagman drainage basin is approximately bounded on the northeast by the drainage basin of Kannat Halaihai Stream valley (fig. 2). No single stream drainage basin demarks the southwestern boundary, but the major stream in this area is the Kannat Taddong Laolao (fig. 2). Both of these streams are intermittent and drain areas mainly underlain by limestone. Another intermittent stream, Kannat Taddong Papago (fig. 2), 


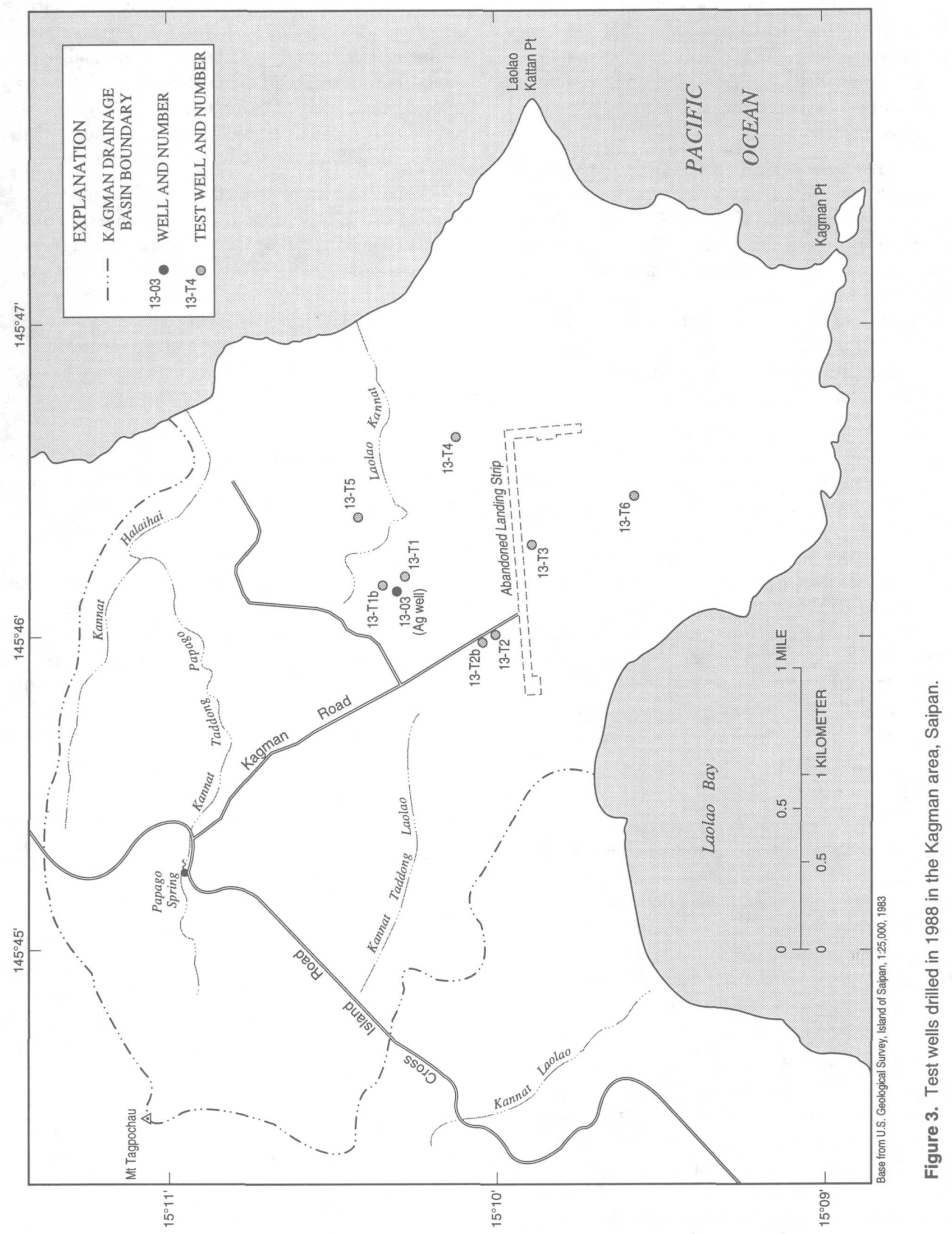


near the center of the basin, drains an area underlain by volcanic sediments and limestones. An intermittent spring, Papago (fig. 2), is near a contact between limestone and volcanic rocks. This spring drains into the Kannat Taddong Papago Stream. The northwestern boundary of the basin is defined by the upper slopes of Mt. Tagpochau (fig. 2).

The predominant physical feature in the Kagman drainage basin is the Kagman Peninsula. The peninsula is a flat limestone platform about 200 to $250 \mathrm{ft}$ above mean sea level with an area of about $4 \mathrm{mi}^{2}$. No perennial streams exist within the Kagman drainage basin. One small intermittent stream, Laolao Kannat (fig. 2), exists on the peninsula. Within the Kagman drainage basin, a variety of disturbed or secondary vegetation communities are found and the dominant species in the peninsula area is tangantangan (Leucaena leucocephala).

The climate in Saipan is classified as tropical marine with an average temperature of about $75^{\circ}$ to $80^{\circ} \mathrm{F}$ and mean annual rainfall of about 80 in. (van der Brug, 1985). Rainfall in the study area is seasonal and averages about 75 to $80 \mathrm{in} / \mathrm{yr}$. The wet season is usually from July through November, followed by a dry season from December through June. Infiltration on Saipan is high because the limestone that constitutes 90 percent of the island's surface is highly permeable and is generally covered only by a thin veneer of soil. In the Kagman area the soil thickness ranges from 40-50 in. and is characterized as well drained.

\section{GEOLOGY}

Saipan is composed of various types of constructional and bioclastic marine limestones, sandstones, shales, and reworked volcanic sediments deposited on a series of dacitic and andesitic lava flows (Cloud and others, 1956). A complex history of emplacement, erosion, redeposition, and faulting has produced a complicated pattern in the relation among rock types. A comprehensive geologic description of Saipan is given by Cloud and others (1956).

Three geologic formations crop out in the Kagman drainage basin. The surface distribution of the three major formations and a member of one of the formations is shown in figure 4 . The rocks are composed primarily of limestones and a lesser amount of volcanically derived sediments. The youngest formation is the Pleistocene age Mariana Limestone, which forms most of the peninsula, ranges in thickness from 300 to $500 \mathrm{ft}$, and extends below sea level. The Mariana Limestone is composed mostly of finely to coarsely fragmented, commonly coralliferous, algal, and, in part, clayey limestone. The Mariana typically is white to grey colored, moderately to cavernously porous, and nonbedded to indistinctly bedded. Freshwater floats on the underlying saltwater in the permeable limestone.

The volcanically derived Donni Sandstone, a member of the Tagpochau Limestone, underlies the Mariana Limestone. The Donni Sandstone ranges in thickness from 100 to $300 \mathrm{ft}$ and is composed of wellbedded, tuffaceous marine sandstone, siltstone, and marly and shaley beds. The sandstone crops out to the west of the Mariana Limestone and dips about 15 degrees to the southeast. The Donni Sandstone has comparatively low permeability and constitutes a confining unit in the study area.

The calcareous rocks of the Miocene to Pliocene age Tagpochau Limestone, west of the Donni Sandstone member, are found in the upper reaches of the drainage basin. The Tagpochau Limestone ranges in thickness from 500 to $1,000 \mathrm{ft}$ and includes clastic rocks of volcanic origin, and compact, pure-to-clayey, whiteto-pink, inequigranular carbonate deposits. The Tagpochau dips to the southeast and underlies the Donni Sandstone over most of the area. Most of the Tagpochau is more sandy than the Mariana Limestone. The permeable calcareous facies of the Tagpochau Limestone have good water-yielding properties. Freshwater floats on the underlying saltwater.

Also cropping out on the slopes of Mt. Tagpochau, in subordinate amounts, is the Eocene age Densinyama Formation. The Densinyama Formation is a series of deeply weathered, volcanically derived sediments including andesitic breccias, conglomerates, and sandstones. The thickness of the Densinyama Formation has been estimated at about $500 \mathrm{ft}$ (Cloud and others, 1956). Few wells have been drilled into the formation, thus its thickness and aerial extent are unknown. The volcanic sediments of the Hagman Formation probably underlie the Densinyama Formation and possibly underlie parts of the Tagpochau Limestone.

Generalized geologic sections constructed on the basis of selected geologic logs of wells drilled in the drainage basin and from Cloud and others' (1956) geologic map are shown in figure 5 . The sections show the subsurface geology of the drainage basin from the 


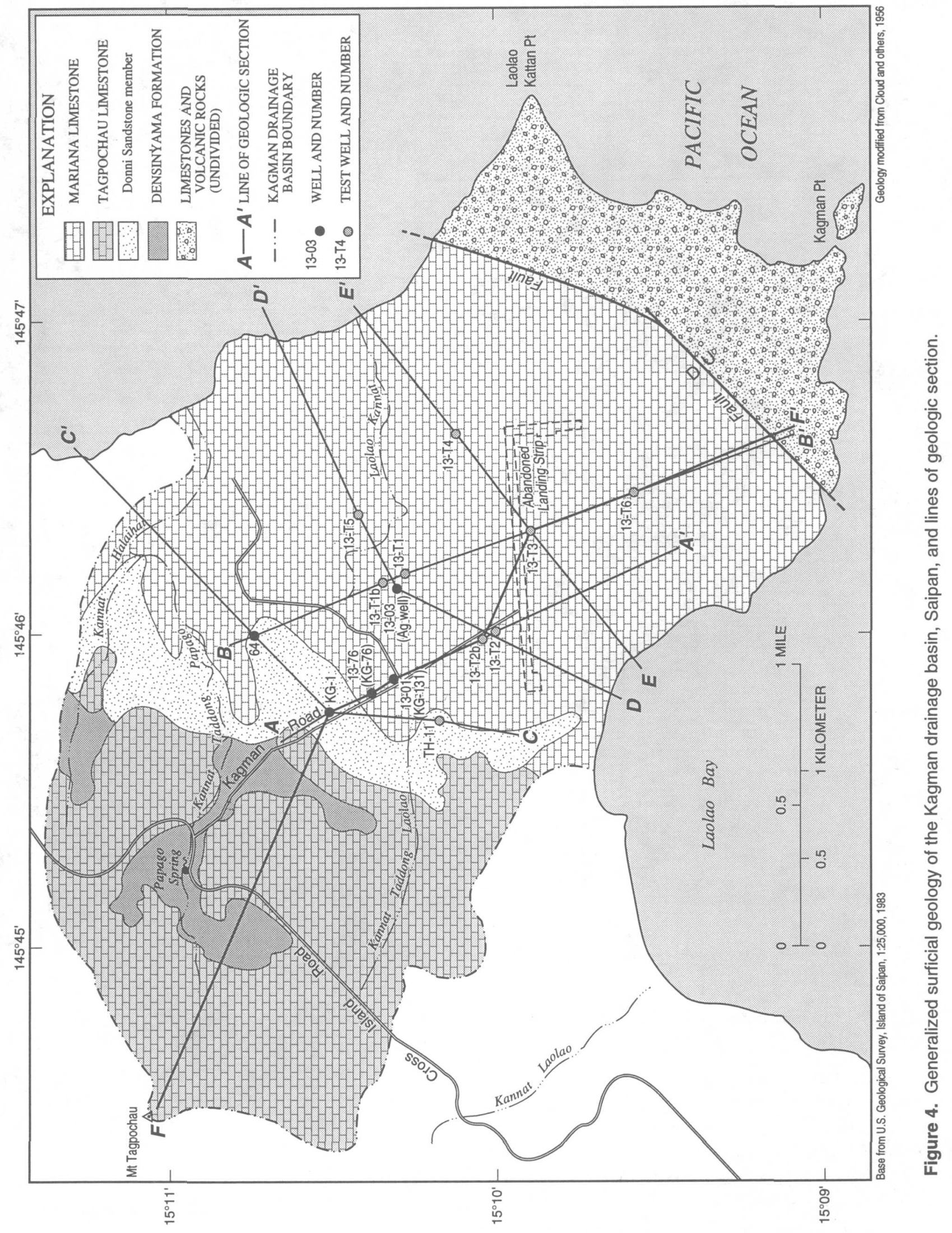



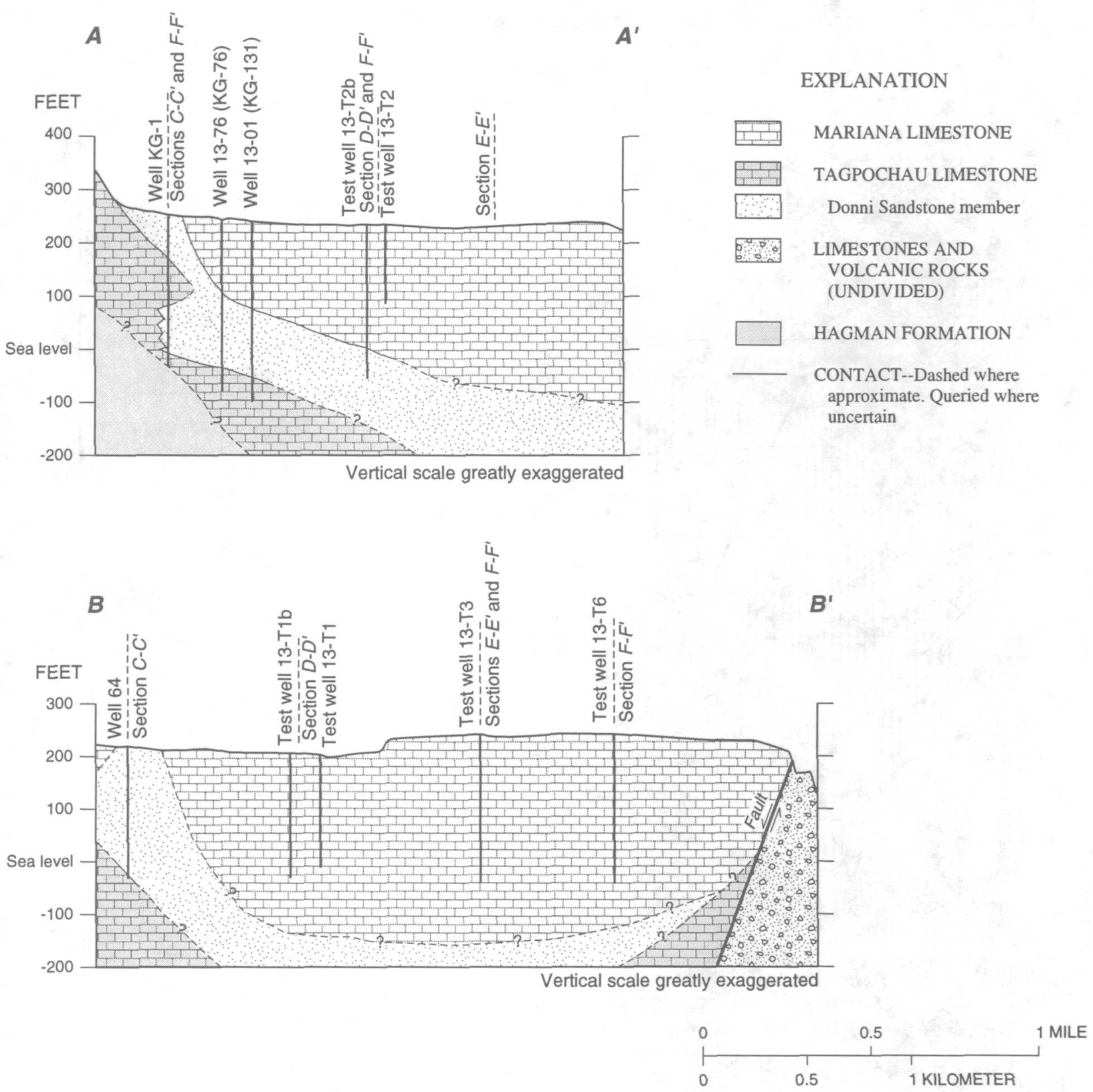

Figure 5. Generalized geologic sections, Kagman area, Saipan (location of sections shown in fig. 4).

summit of Mt. Tagpochau to the southeastern edge of the Kagman Peninsula.

The fault shown in figure 4, near the ocean end of the peninsula, is the southeastern boundary of the study area in the Kagman drainage basin. This fault is a highangle normal fault with upward dip-slip movement on the southeastern side (see sections B- $\mathrm{B}^{\prime}$ and F-F' in fig. 5). The southeastern side has been uplifted so that sedimentary rocks of volcanic origin are found well above sea level. No water-level data exist for this part of the peninsula; therefore, how this fault may affect the flow of ground water in the Mariana Limestone is uncertain. Movement of ground water may be impeded along the fault zone causing higher water levels near the center of the peninsula.

To define the hydrologic characteristics of the Mariana Limestone, nearly all of the test-drilling was done in this formation. However, one test well, 13-T2b, 

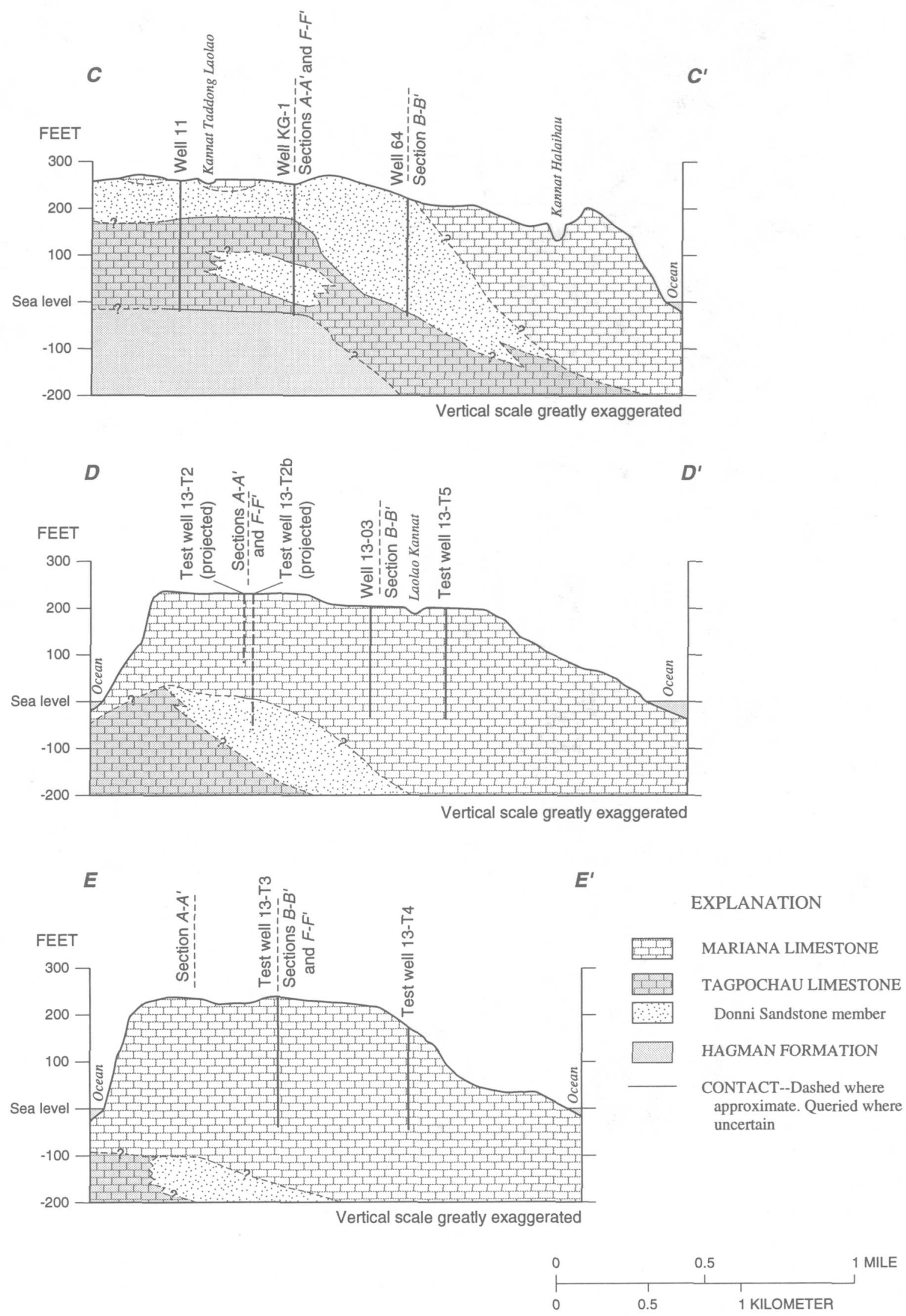

Figure 5. Generalized geologic sections, Kagman area, Saipan (location of sections shown in fig. 4)--Continued. 


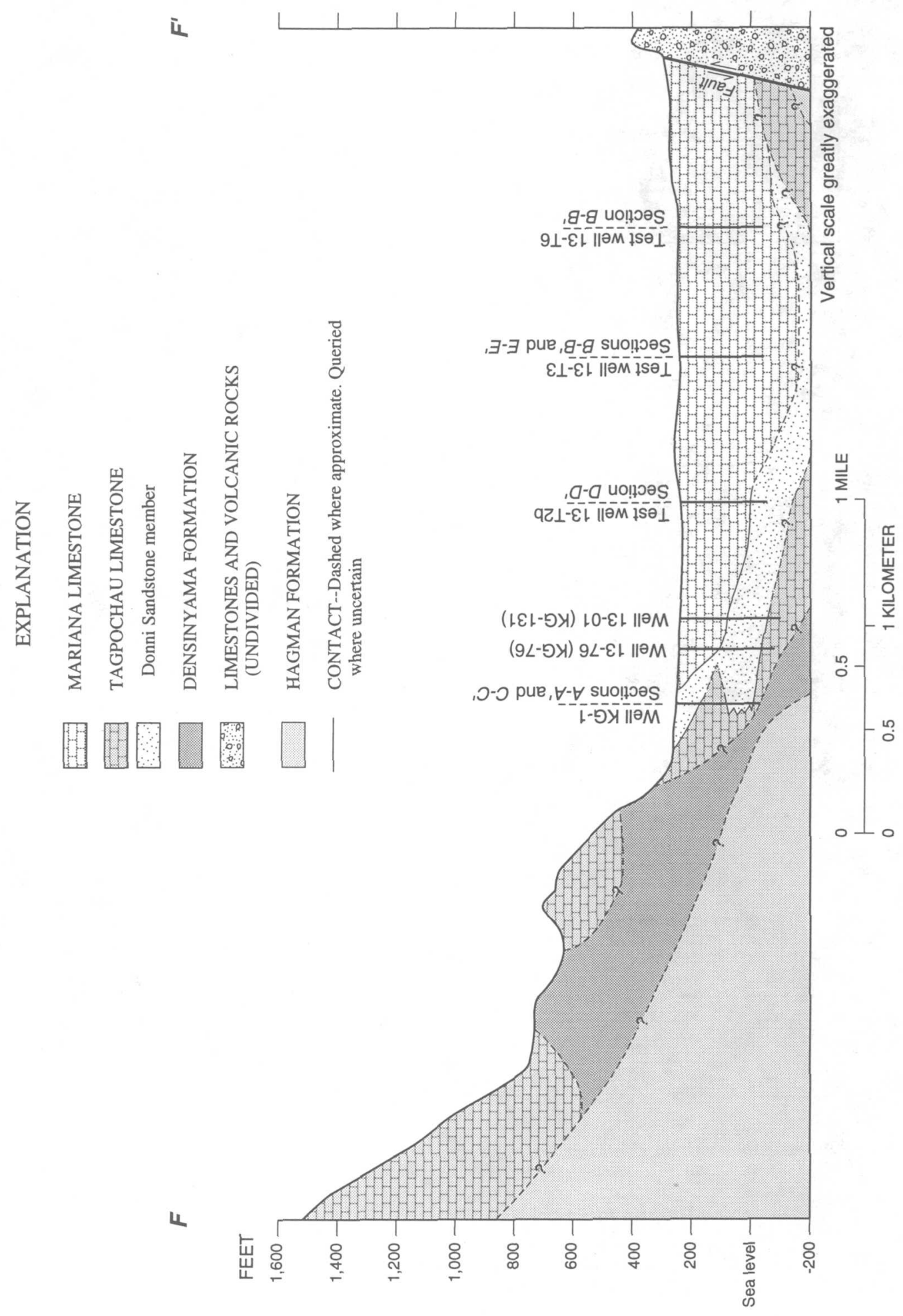

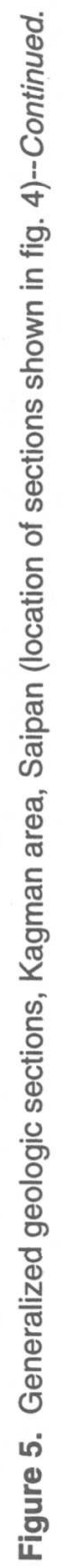




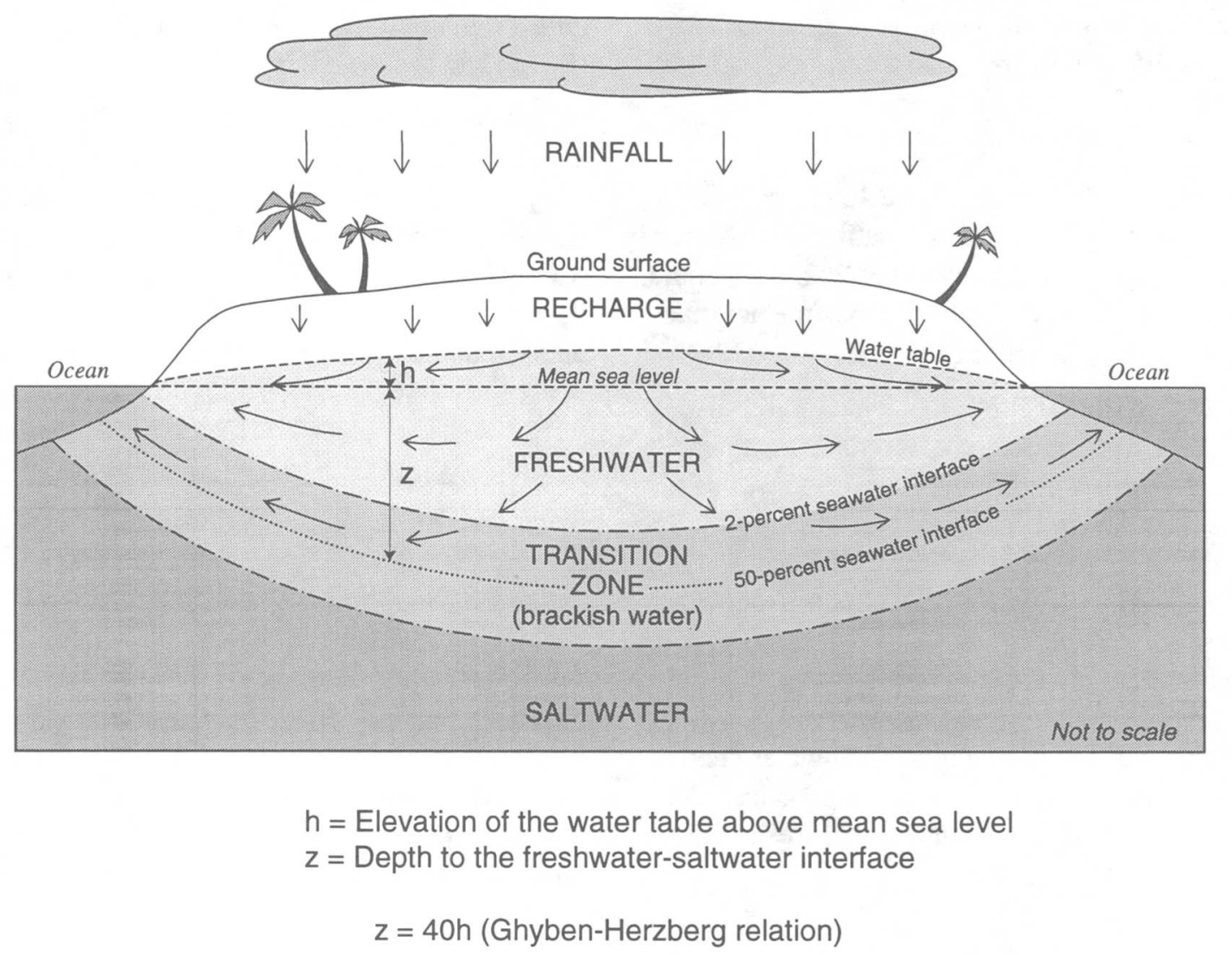

Figure 6. Idealized occurrence of fresh and saline ground water in an unconfined island aquifer.

was completed in the Donni Sandstone. The generalized geologic sections shown in figure 5 were constructed on the basis of geologic logs of the test wells and of other previously drilled wells.

\section{GROUND-WATER OCCURRENCE AND MOVEMENT}

On small oceanic islands such as Saipan, fresh ground water originates entirely from rainfall. A lensshaped freshwater body, shown schematically in figure 6 , is formed by the density difference between fresh recharge water and underlying saltwater derived from the ocean. The freshwater lens floats on denser, underlying saltwater. For the purposes of this study, freshwater (potable water) is defined as water that has less than 2-percent of the chloride-ion concentration in seawater (about $380 \mathrm{mg} / \mathrm{L}$ of chloride). A transition zone between fresh and saline ground water occurs from dispersion and the combined effects of tidal, atmospheric, and rainfall fluctuations (Todd, 1980).
The depth to the 50-percent freshwater-saltwater interface can be estimated by the Ghyben-Herzberg relation and is a good approximation of the freshwater lens thickness when the transition zone is thin relative to the thickness of the lens. For hydrostatic conditions, if the specific gravities for freshwater and saltwater are 1.000 and $1.025 \mathrm{~g} / \mathrm{cm}^{3}$ respectively, the Ghyben-

Herzberg relation predicts that every foot of freshwater above sea level is balanced by $40 \mathrm{ft}$ of water below sea level. The water table, or potentiometric surface, typically is only one to several feet above mean sea level in the Kagman Peninsula area.

The Mariana and Tagpochau Limestones make up the aquifer system in the Kagman area. Ground water is unconfined in the Mariana Limestone and ranges from unconfined to confined in the Tagpochau Limestone. Depth to the water table in the Mariana Limestone ranges from about 173 to $241 \mathrm{ft}$ in the six test wells. The altitude of the water table fluctuates daily and seasonally. During this study, the altitude of the water table varied seasonally from about 1.5 to $2.5 \mathrm{ft}$ above mean 
sea level and daily variátions were as much as $0.2 \mathrm{ft}$. Dry season monitoring from January to June 1989 indicates that water levels in the Mariana Limestone declined an average $0.5 \mathrm{ft}$.

Freshwater in the Mariana Limestone grades into saltwater with a transition zone separating the two. On the basis of the results of this study, the thickness of the potable freshwater layer is about 10 times the height of the water table above mean sea level.

Water in the Tagpochau Limestone aquifer also is in direct contact with saltwater. Records from abandoned and active production and observation wells indicate that the Tagpochau Limestone has water levels 15 to $30 \mathrm{ft}$ above sea level in the northwestern parts of the peninsula. No data exist on the thickness and depth of the transition zone between freshwater and seawater in the Tagpochau Limestone. The poorly permeable Donni Sandstone may retard the seaward movement of freshwater and cause the buildup of freshwater head in the otherwise highly permeable limestone. Data collected from test well 13-T2b indicate that freshwater is present in the Donni Sandstone.

\section{Ground-Water Recharge}

The primary source of water to the ground-water system in the Kagman drainage basin is from direct infiltration of rainfall. Additionally, minor groundwater inflow may occur from upgradient ground water outside of the Kagman drainage basin. The Mariana and Tagpochau Limestones have high permeability and greater aerial distribution relative to the Donni Sandstone, and receive most of the ground-water recharge, but the actual rates of recharge are unknown. Although the Donni Sandstone is less permeable than the limestones, recharge to this unit cannot be neglected in an analysis of total ground-water availability in the area.

Rainfall records for Saipan are available for most years since 1901 from German, Japanese, and U.S. sources; however, rain-gage locations before World War II are not precisely known. The most complete rain-gage data have been collected since 1968. Rainfall data were collected at the Kagman Communication Center (fig. 1) during 1968-84, and at the Kagman Agriculture Station during 1976-84. Discontinuously since 1977, the USGS has maintained rain gages at the Nine Million Gallon Reservoir and near Saipan's International Airport at Isley Field (fig. 1). A rain gage main- tained by the CNMI government in the Capitol Hill area (fig. 1) has been in operation since 1986.

Rainfall in the study area is seasonal, but averages about 75 to $80 \mathrm{in} / \mathrm{yr}$. About $65 \mathrm{in} / \mathrm{yr}$ is recorded at the Isley Field rain gage (fig. 1). Two rain gages were installed near the summit of Mt. Tagpochau in 1990. Rainfall measured at the Mt. Tagpochau gages exceeds that at other sites by about 20 percent and may indicate an orographic effect; however, a longer period of record is needed to make a determination of rainfall distribution.

No perennial streams exist in the Kagman drainage basin and for the purposes of estimating ground-water recharge in the study area, surface-water runoff is considered negligible. Infiltration on Saipan is high because (1) the limestone that constitutes 90 percent of the island's uppermost rock unit is highly permeable and (2) the limestone generally is covered only by a thin veneer of soil. In the Kagman area the soil thickness ranges from 40 to 50 in. and is characterized as well drained (Natural Resources Conservation Service, personal commun., 1997). The streams in the study area usually flow only after periods of high intensity rainfall associated with tropical cyclones. The absence of perennial streams indicates that as much as half of the rainfall may infiltrate below the surface to recharge the ground-water system.

No evaporation or transpiration data have been collected on Saipan. However, a range of estimated evapotranspiration values has been published in earlier studies. Cox and Evan (1956), Davis (1973), M \& E Pacific (1978), and Ayers (1981) estimated the annual evaporation to be about $30 \mathrm{in}$., which is about 40 percent of the annual rainfall. Van der Brug (1985) argued that an annual evaporation of $30 \mathrm{in}$. is too low because the estimated annual mean pan evaporation for Guam is 54 in., or about 56 percent of the annual rainfall. Mink (1987) summarized water-balance studies and estimated evapotranspiration to be 40 to 50 percent of pan evaporation. Applying this factor to the Guam annual pan evaporation of $77 \mathrm{in} / \mathrm{yr}$ results in an evapotranspiration rate of 31 to $39 \mathrm{in} / \mathrm{yr}$.

Assuming 56 percent of rainfall in the Kagman drainage basin is lost back to the atmosphere by evapotranspiration and that surface-water runoff is negligible, then ground-water recharge is about 33 to $35 \mathrm{in} / \mathrm{yr}$. Over the $8 \mathrm{mi}^{2}$ basin, this recharge is about $13 \mathrm{Mgal} / \mathrm{d}$ (total annual recharge averaged on a daily basis). The area 
Table 1. Sea-level fluctuation and borehole water-level fluctuations for selected timespans, Kagman area, Saipan $[\sim$, approximately; $\leq$, less than or equal to; --, not calculated]

\begin{tabular}{ccccc}
\hline Test well & $\begin{array}{c}\text { Period of } \\
\text { water-level records } \\
\text { (month/day/year) }\end{array}$ & $\begin{array}{c}\text { Water-level } \\
\text { fluctuation } \\
\text { (feet) }\end{array}$ & $\begin{array}{c}\text { Sea-level } \\
\text { fluctuation } \\
\text { (feet) }\end{array}$ & $\begin{array}{c}\text { Tidal efficiency } \\
\text { (percent) }\end{array}$ \\
\hline 13-T1b & $1 / 17-19 / 89$ & $0.10-0.15$ & $\sim 2.5$ & -- \\
13-T2b & $12 / 07-16 / 88$ & $\leq .07$ & 2.5 & -- \\
13-T3 & $12 / 25-28 / 88$ & $0.07-0.11$ & $1.7-2.5$ & 4 \\
13-T4 & $12 / 17-27 / 88$ & $0.20-0.32$ & $2.5-3.0$ & 10 \\
13-T5 & $1 / 12-19 / 88$ & $0.10-0.30$ & $1.0-3.0$ & 9 \\
13-T6 & $12 / 19-23 / 88$ & $0.16-0.29$ & $2.3-3.0$ & 9 \\
\hline
\end{tabular}

underlain by the upper part (Mariana Limestone) of the aquifer system is about 70 percent of the total area; therefore the upper part of the aquifer system may receive about $9 \mathrm{Mgal} / \mathrm{d}$ of ground-water recharge. If the evapotranspiration rate is about 40 percent of rainfall and surface-water runoff is negligible, then groundwater recharge would be about $18 \mathrm{Mgal} / \mathrm{d}$. The actual rates of recharge probably are lower than the estimated rates because of the assumption that surface-water runoff is negligible. Intermittent streams in the study area may have significant total and mean annual flow. The above calculations are rough estimates of the actual rates of recharge and indicate that recharge of ground water is high compared with the projected municipal and agricultural water demand of $2 \mathrm{Mgal} / \mathrm{d}$.

\section{Water-Level Fluctuations}

Altitude of the water table in the Mariana Limestone was measured in all the test wells in January, June, and September 1989. Continuous recordings of water levels also were made for several days before and after aquifer tests in all the test wells in which aquifer tests were done. Water levels in test well 13-T5 were measured continuously from mid-January to early February and from early March to mid-April 1989 (fig. 7).

Data collected during this study indicate that daily water-level changes induced by sea-level fluctuations are as much as $0.2 \mathrm{ft}$ in the Mariana Limestone. Waterlevel fluctuations at the test wells were compared with sea-level fluctuations over the same time period from the tide gage at Charlie Dock Harbor, Saipan (Klaus Wyrtki, University of Hawaii, written commun., 1989). Water-level fluctuations in test wells completed in the Mariana Limestone, except in well 13-T1b, occurred at the same frequency as the tidal frequency; however, the amplitude of the response was about 10 percent of the ocean tide (table 1). The water-level fluctuations in test well 13-T2b, completed in the Donni Sandstone, were different from the water-level fluctuations in wells completed in the Mariana Limestone. The water-level fluctuations in test well 13-T2b were semi-diurnal and corresponded to barometric pressure variation. No tidal-induced water-level fluctuation was observed in test well 13-T2b.

Seasonal water-level fluctuations were recorded in the test wells. Water levels in wells drilled into the Mariana Limestone declined from an average altitude of 2.5 $\mathrm{ft}$ in January 1989 to $2.0 \mathrm{ft}$ in June 1989. During this period, a maximum decline of $0.6 \mathrm{ft}$ was recorded in test well 13-T5 and a minimum decline of $0.30 \mathrm{ft}$ was measured in test well 13-T1b. The observed water-level declines correspond to the onset of the dry season and to an overall decline in sea level measured at the Agana Harbor tide gage (unpub. data in files at USGS, Hawaii District office) located about $150 \mathrm{mi}$ south of the Kagman area on Guam. The tide-gage record indicates a similar range of average sea-level decline during the same time period (fig. 7).

\section{Ground-Water Movement}

Fresh ground water in the Kagman drainage basin moves downgradient from higher heads in the mountainous interior areas toward lower heads at discharge areas along the coast. The general movement of ground water in the Tagpochau and Mariana Limestones is shown in figure 8 . Fresh ground water moves from Tagpochau-Limestone into saltwater and the Donni Sandstone, from Donni Sandstone into saltwater and the Mariana Limestone, and from the Mariana Limestone into saltwater and the undivided limestones and 


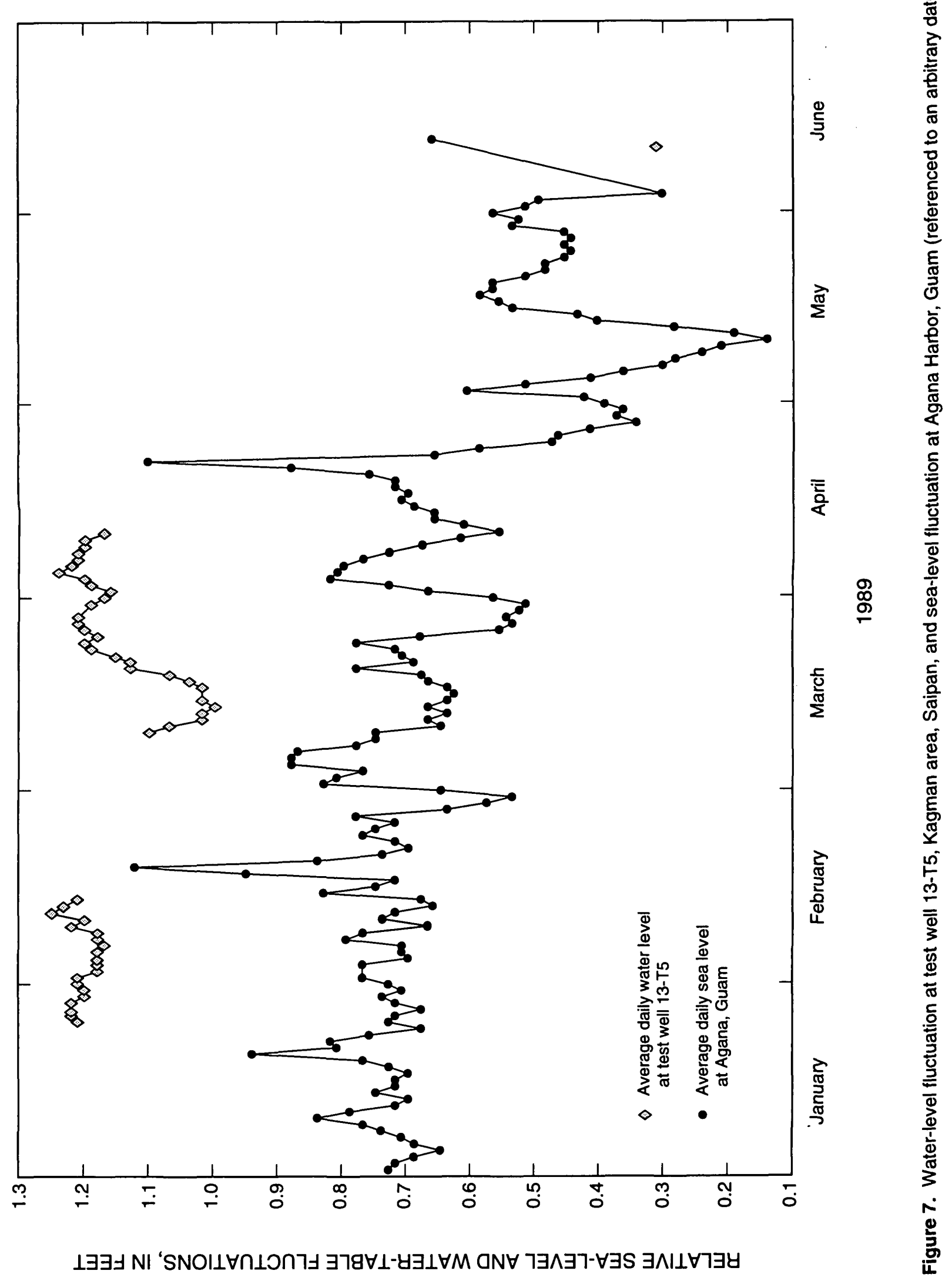


占

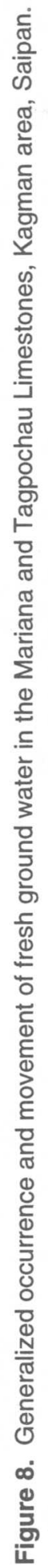


volcanic rocks. Freshwater discharges from the limestones to the ocean and to pumping.

Water-level data indicate that water is moving upward from the Tagpochau Limestone into Donni Sandstone and subsequently into the Mariana Limestone, which is consistent with the general pattern of ground-water movement shown in figure 8 . Test well 13-T2b was completed in the Donni Sandstone and has a water level about $2.5 \mathrm{ft}$ higher than nearby test wells in the Mariana Limestone aquifer. Wells drilled into the Tagpochau Limestone below the Donni Sandstone have water levels as much as $30 \mathrm{ft}$ above sea level, about 28 $\mathrm{ft}$ higher than the water-level altitude in the Mariana Limestone.

Water-level altitude data in the Mariana Limestone are shown in figures 9,10 , and 11 . Water levels shown are for January, June, and September 1989, respectively, and represent the beginning of the dry season, the end of the dry season, and the middle of the wet season. The water levels shown in figures 9 and 10 were measured over a period of about 1 hour. Because the tide will not change significantly during the course of 1 hour, the gradients shown probably are not influenced by tidal fluctuation. Water levels shown in figure 11 represent an average for those measured during September 7-14, 1989. The figures show a similar shape of the water-table surface throughout the seasons. A groundwater divide is located roughly in the middle of the peninsula and the direction of flow is perpendicular to the lines of equal water level, from inland toward the seaward edges of the peninsula.

\section{Thickness of the Freshwater Lens}

The vertical thickness of the freshwater lens was estimated in each of the test wells in the Mariana Limestone during June 2-5, 1989. Water samples were collected at 5-ft intervals with a point-sampling bailer from the open boreholes. The samples were collected from successively greater depths in order to obtain water from the undisturbed water column and were analyzed for chloride-ion concentration. At the time of sampling, the altitude of the water table in the Mariana Limestone ranged from about 1.5 to $2.5 \mathrm{ft}$. The corresponding thickness of the freshwater lens is shown in figure 12 . As stated previously, the lower limit of the freshwater lens is defined by a chloride-ion concentration of 2-percent that of seawater $(380 \mathrm{mg} / \mathrm{L})$. Results of the analysis indicate that the thickness of the freshwater lens ranged from about 15 to about $21 \mathrm{ft}$, about 10 times the height of the water table above mean sea level.

The thickness of the freshwater lens at well 13-T1b could have been affected by pumping at nearby well 1303 (Ag. well) (fig. 12). Pumping at well 13-03 was intermittent, however, and water levels measured at a given time may not indicate the effect of pumping on lens thickness. The procedure used to determine lens thickness required 4 days to complete (June 2-5, 1989); therefore, the thickness shown in figure 12 is not a synoptic representation of the lens. However, owing to the low tidal efficiency, the lens thickness and chloride-ion concentration values in figures 12 and 13 probably are representative of the actual values.

A geohydrologic section through the lens along trace G- $\mathrm{G}^{\prime}$, constructed on the basis of chloride-ion concentrations, illustrates the configuration of the freshwater lens (fig. 13). The freshwater lens is relatively thin throughout the area occupied by the Mariana Limestone, and the transition to 50-percent is rapid below the line of 2-percent chloride-ion concentration.

On the basis of the range in water-table altitude of 1.5 to $2.5 \mathrm{ft}$, the Ghyben-Herzburg relation would predict the depth to the 50-percent seawater chloride-ion concentration to range from about 60 to $100 \mathrm{ft}$ below mean sea level. However, the 50-percent seawater chloride-ion concentration $(9,500 \mathrm{mg} / \mathrm{L})$ was measured at about $30 \mathrm{ft}$ below the water table, indicating a ratio of about 1 to 15 instead of the 1 to 40 ratio predicted by the Ghyben-Herzburg relation. Differences between the actual and predicted values of depth to 50-percent freshwater-saltwater interface may be attributable to the simplifying assumptions of the Ghyben-Herzburg relation. The Ghyben-Herzburg relation gives satisfactory results in areas where ground-water flow is nearly horizontal; however, near the shoreline, where vertical flow components become pronounced, significant errors in the prediction of the position of the interface can occur (Todd, 1980).

Another contributing factor to the discrepancy between the actual and predicted values of depth to the 50-percent freshwater-seawater interface may be the effects of non-tidal sea-level fluctuations that are transmitted in the aquifer. These non-tidal, atmospherically forced sea-level fluctuations, which occur at daily to interannual time scales in the equatorial Pacific, can influence ground-water levels (Hunt, 1997). A review 


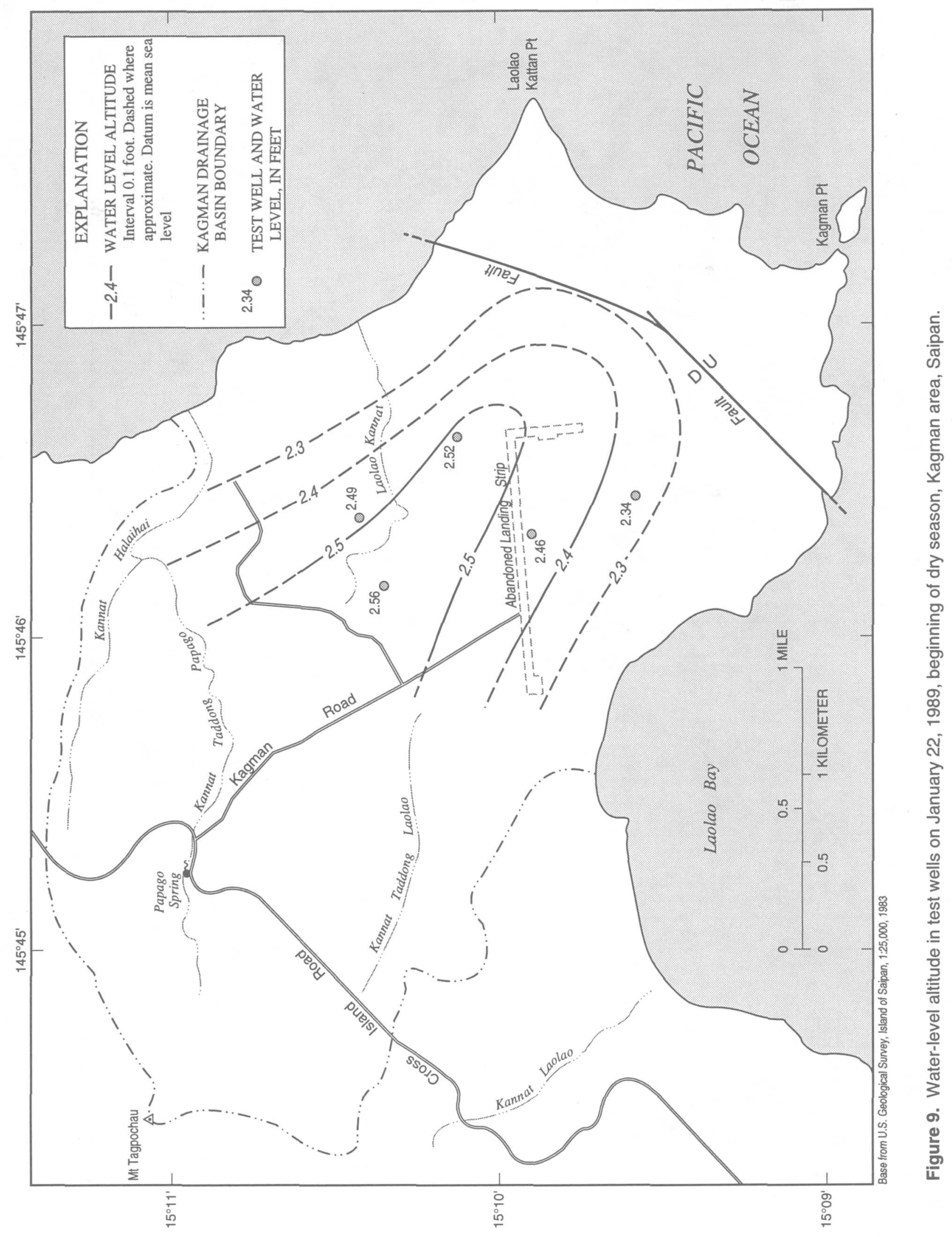




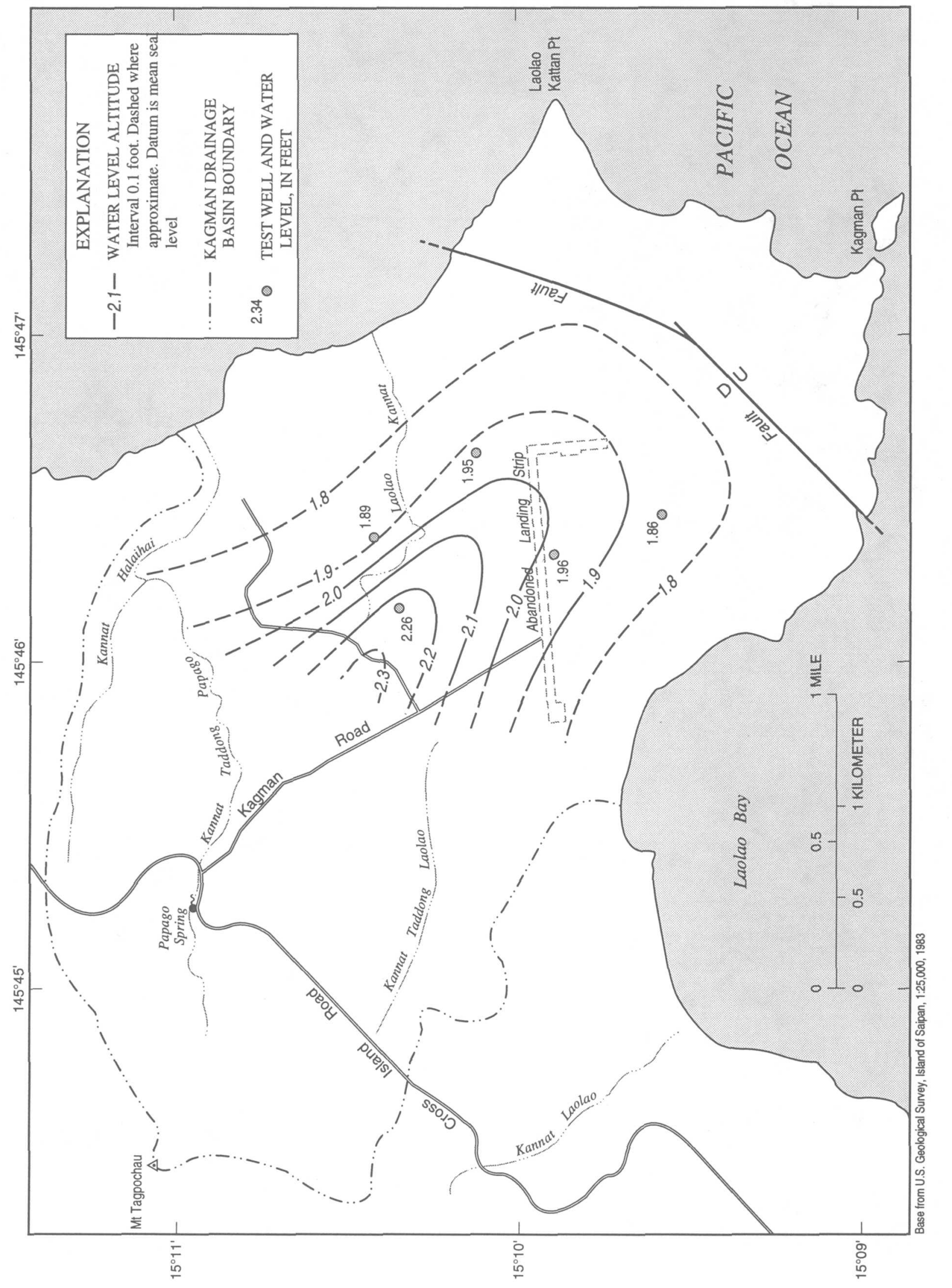

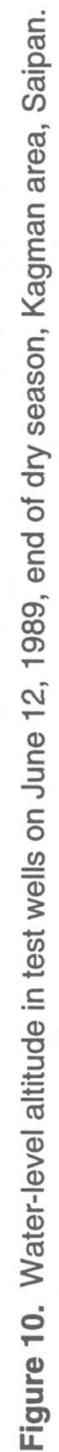




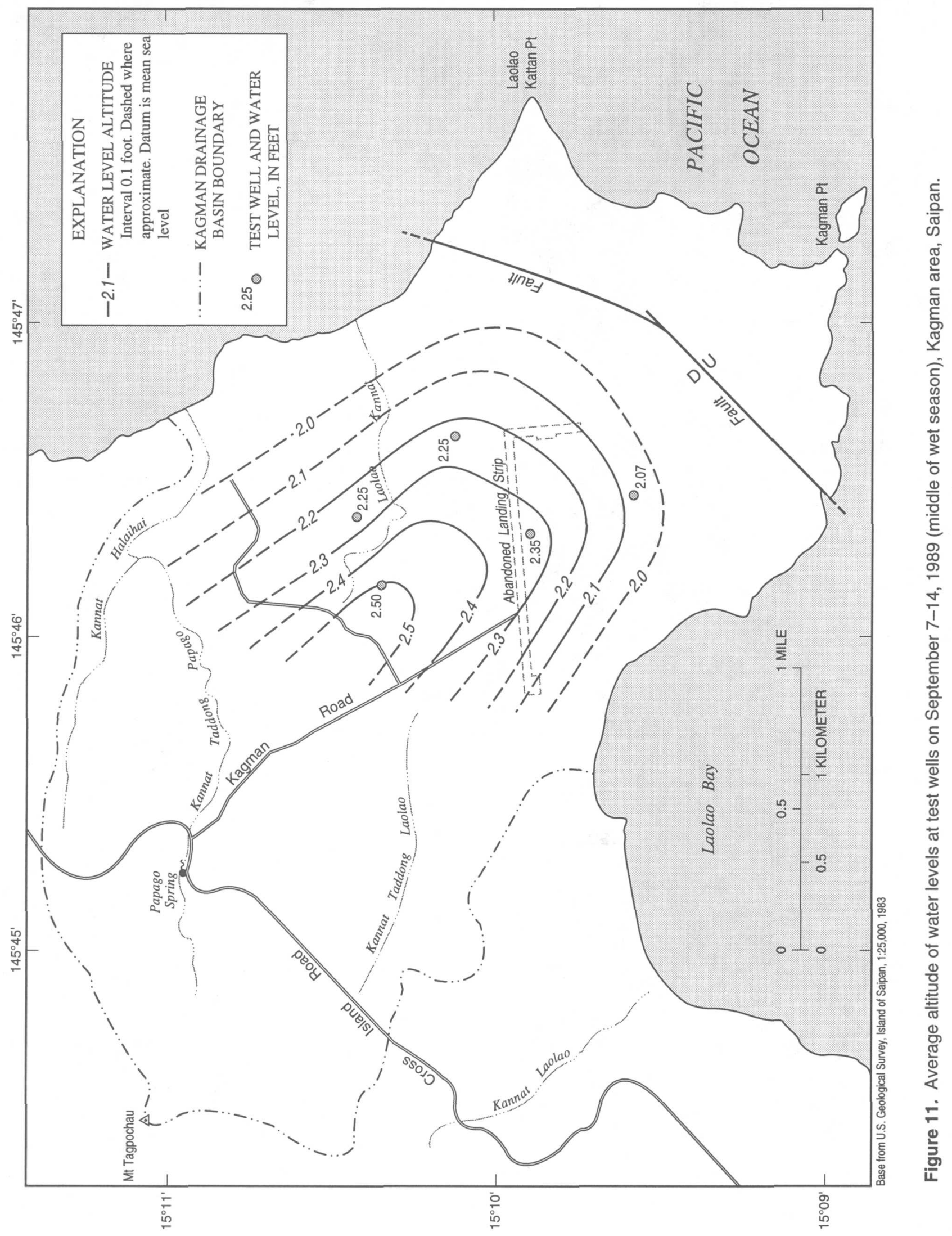




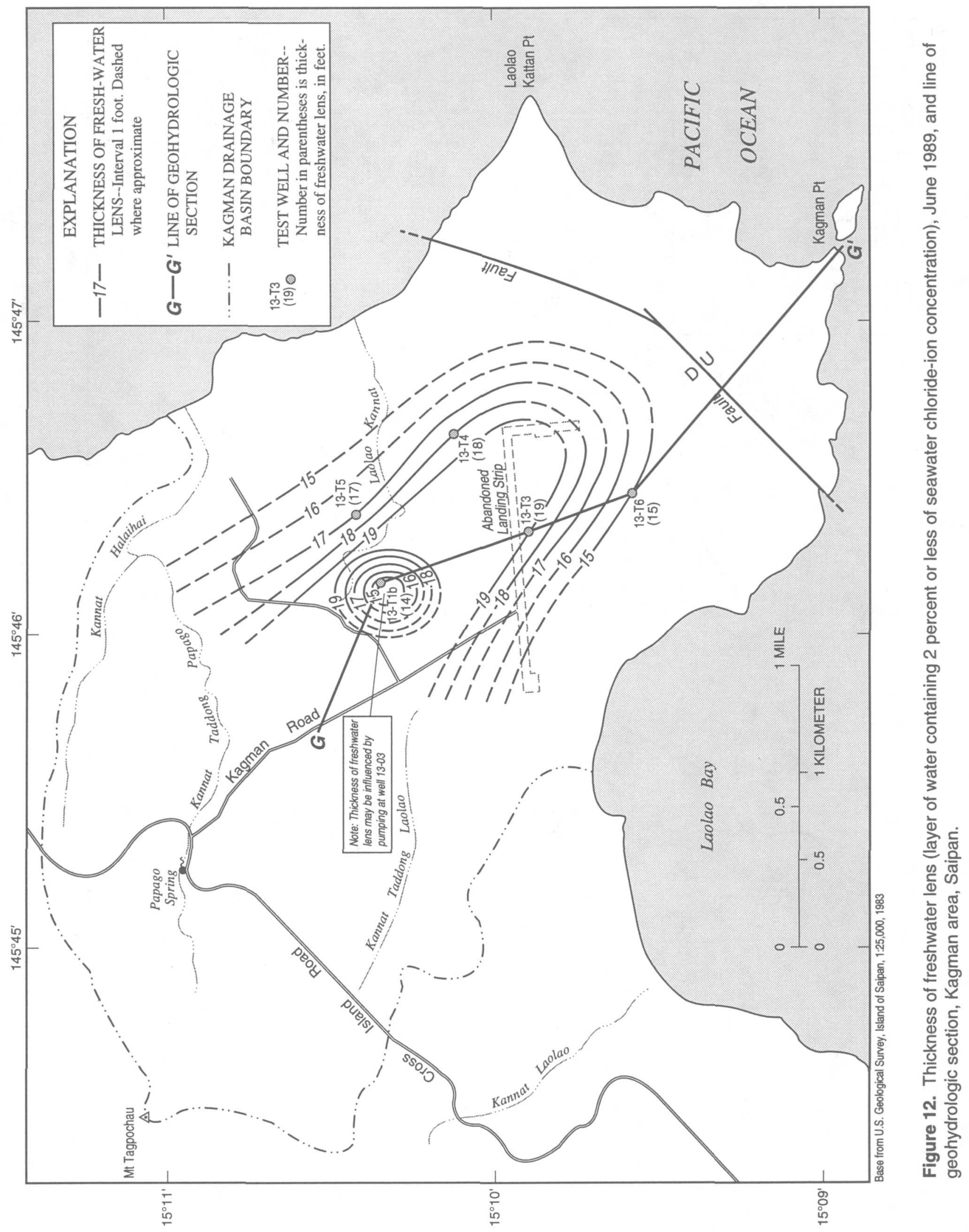




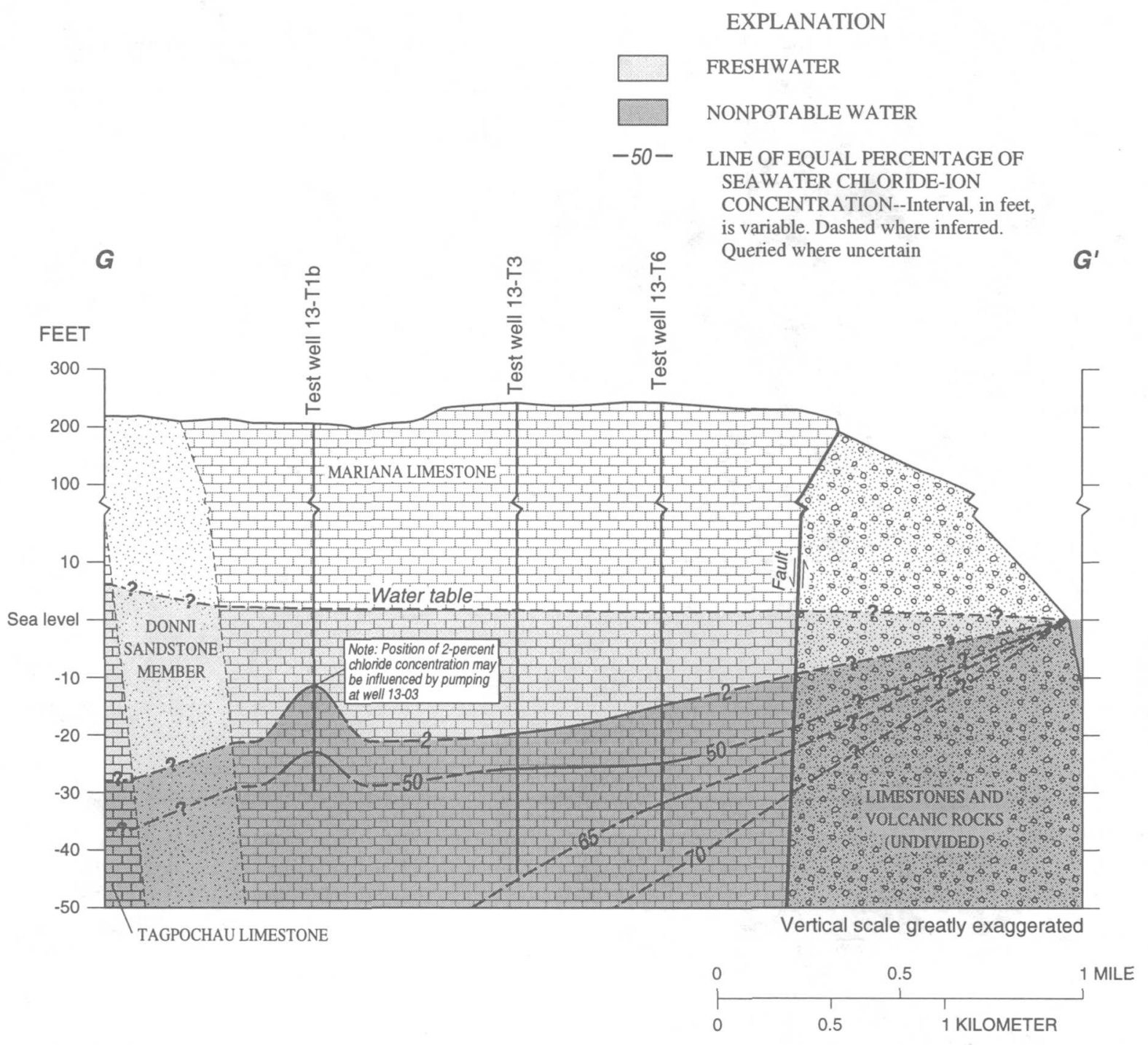

Figure 13. Generalized geohydrologic section showing lines of equal percentage of seawater chloride-ion concentration, Kagman area, Saipan, June 1989 (location of section shown in fig. 12).

of Saipan sea-level data for June 1989, indicates that average sea level was about $1.5 \mathrm{in}$. above mean sea level during this period (data from University of Hawaii Sea Level Center; URL http://uhslc.soest.hawaii.edu; accessed March 2, 1998; last updated December 2, 1997). If the average sea level was higher than mean sea level (the datum to which ground-water levels are referenced) during the time of measurement of water-table altitude, the measured altitude of the water-table surface might be greater than the actual value, causing the Ghyben-Herzburg relation to over-predict the depth to the interface. Additional causes for differences between actual and predicted values of depth to the interface include the effects of ground-water withdrawal, mixing of fresh and saline ground water induced by the tidal fluctuation, and geologic heterogeneity.

Chloride-ion concentration profiles from water samples in test wells 13-T1b through 13-T6 during June 1989 are shown in figure 14. The profiles show that, although test wells in the Mariana Limestone do not penetrate into the zone of 100-percent seawater chloride-ion concentration, the transition zone is about twice the thickness of the freshwater lens. Depth from the water-table surface to the 50 -percent seawater 

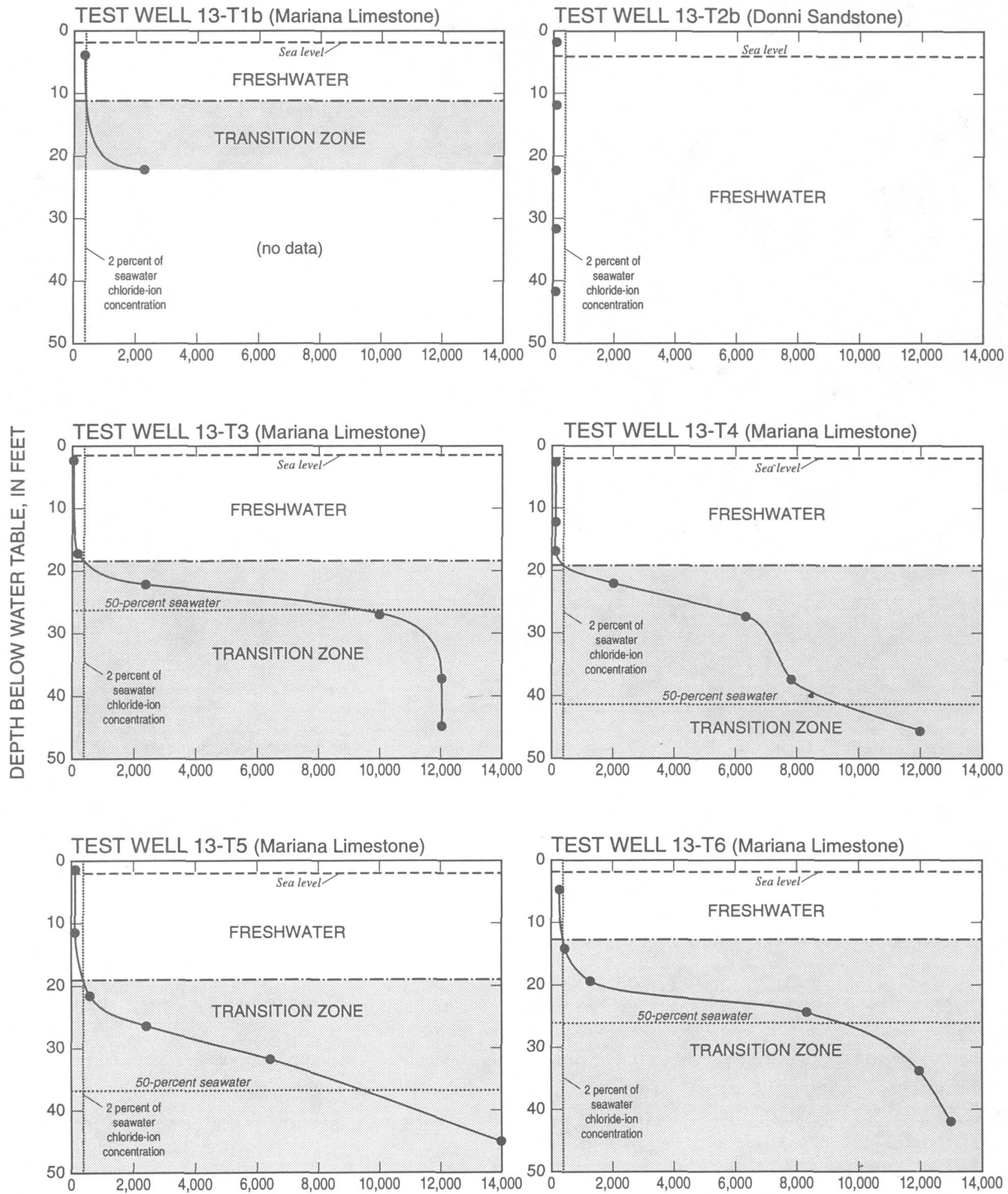

CHLORIDE-ION CONCENTRATION, IN MILLIGRAMS PER LITER

Figure 14. Chloride-ion concentration profiles in test wells, Kagman area, Saipan, June 2-5, 1989. 
concentration is greater on the northeast side of the peninsula, indicated by data collected from test wells 13-T4 and 13-T5, than that on the southwest side, indicated by data collected from test wells 13-T3 and 13-T6. The thicker transition zone on the northeast side of the peninsula may be a result of mixing caused by a higher tidal efficiency in the vicinity of wells 13-T4 and 13-T5.

\section{GROUND-WATER DEVELOPMENT}

\section{History of Well Drilling}

The northwestern part of the Kagman area has been an area of ground-water exploration and development since 1944. Because the Mariana and Tagpochau Limestones constitute a single ground-water system rather than two separate aquifers, all wells from which water is obtained in the Kagman area are discussed. All wells known to have been drilled since 1944 are shown in figure 15. In 1944-45, nine wells were drilled and an infiltration gallery was dug, all in the Tagpochau Limestone. The infiltration gallery penetrated low-permeability rock at the water table and was never finished. The nine wells drilled in 1944 and 1945 by the U.S. military were not needed and were abandoned by 1949 . In 1956, two new wells, 13-76 and 13-78, were drilled into the Tagpochau Limestone. Well 13-76 is still in use as a municipal production well and is referred to as KG76. Use of well 13-78 was discontinued sometime before 1973. The USGS has collected water-level data from well 13-78 since 1973 .

An increase in demand for water for agricultural and domestic use led to more well drilling in the late 1970's and 1980's. In 1976, well 13-03 was drilled into the Mariana Limestone. Well 13-03, referred to as the Kagman agricultural well (Ag. well), presently (1997) is in use to supply irrigation water for the Kagman farm. In 1979, test wells 11 (TH-11) and 12 (TH-12) were drilled into the Mariana Limestone, but for unknown reasons these wells were never put into production. In 1981, well 13-01 was drilled into the Mariana Limestone, but the yield was small. The water level in 13-01 dropped by $60 \mathrm{ft}$ within the first 30 minutes of a pump test. In 1982, the well was deepened into the Tagpochau Limestone. Well 13-01 is now known as well KG-131 and presently (1997) is in use as a municipal supply well.
In 1987, four new wells were drilled into the Tagpochau Limestone. One well, KG-1, reportedly penetrated volcanic rocks at depth and was abandoned. The other wells, 13-04 (KG-2), 13-05 (KG-3), and 13-06 (KG-4), did not penetrate volcanic rocks and have been developed and are in production as of 1997. In 1992, wells KG-5 and KG-6 were completed in the Tagpochau Limestone and put into production to help meet a growing municipal demand.

Further ground-water development was undertaken in the Mariana Limestone in 1991 to meet golf course irrigation requirements. Eight test wells were drilled within the golf course project site from March through May 1991. From 1991 to 1996, an additional 11 test wells were drilled (fig. 15). Fourteen of the test wells have been converted to production wells and are in use as of 1997 to supply water for golf course irrigation. Golf course well 2 was not converted to production because of high salinity. The remaining four test wells are used as monitor wells by golf course maintenance personnel (Tom McKinze, Lau Lau Bay Golf Course, oral commun., 1997) (fig. 15).

In 1995, an increase in demand for potable water in the Kagman homestead area prompted the CUC to drill two more wells in the Mariana Limestone. The wells, KG-7 and KG-8, were completed about $8 \mathrm{ft}$ below sea level and yielded about $30 \mathrm{gal} / \mathrm{min}$ each to the municipal supply in the Kagman area during 1997. Further homestead development probably will lead to more ground-water exploration and development in the Kagman area in the near future.

The locations of all the wells producing from the Kagman drainage basin during 1997 are shown in figure 16. Information on average and instantaneous pump rates and chloride-ion concentrations measured periodically from 1989 to the present are shown in table 2. In 1997, seven wells were producing public-supply water from the Tagpochau Limestone (wells KG-2, $-3,-4,-5$, $-6, \mathrm{KG}-76$, and KG-131). Average rates of pumping in these wells ranged from about 15 to $150 \mathrm{gal} / \mathrm{min}$. The average pump rate of wells in the Tagpochau Limestone was about $61 \mathrm{gal} / \mathrm{min}$ per well. Total pumpage from all the wells was about $223 \mathrm{Mgal} / \mathrm{yr}(612,000 \mathrm{gal} / \mathrm{d})$. Well 13-78 was used as an observation well to monitor water level.

In 1997, seventeen wells were pumping from the Mariana Limestone (well 13-03, wells KG-7, -8, and golf course wells 1 and 3 through 15). Average rates of 


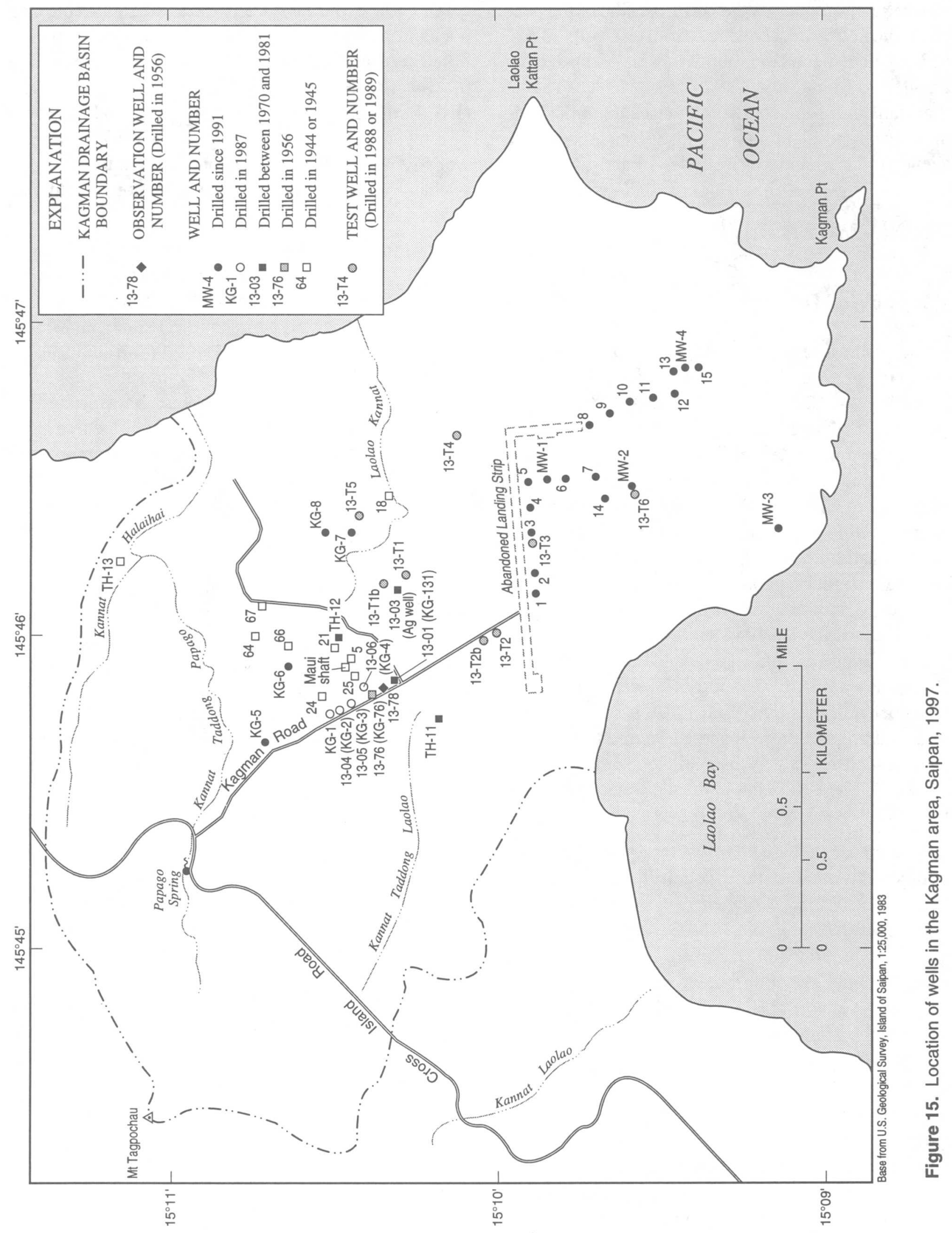




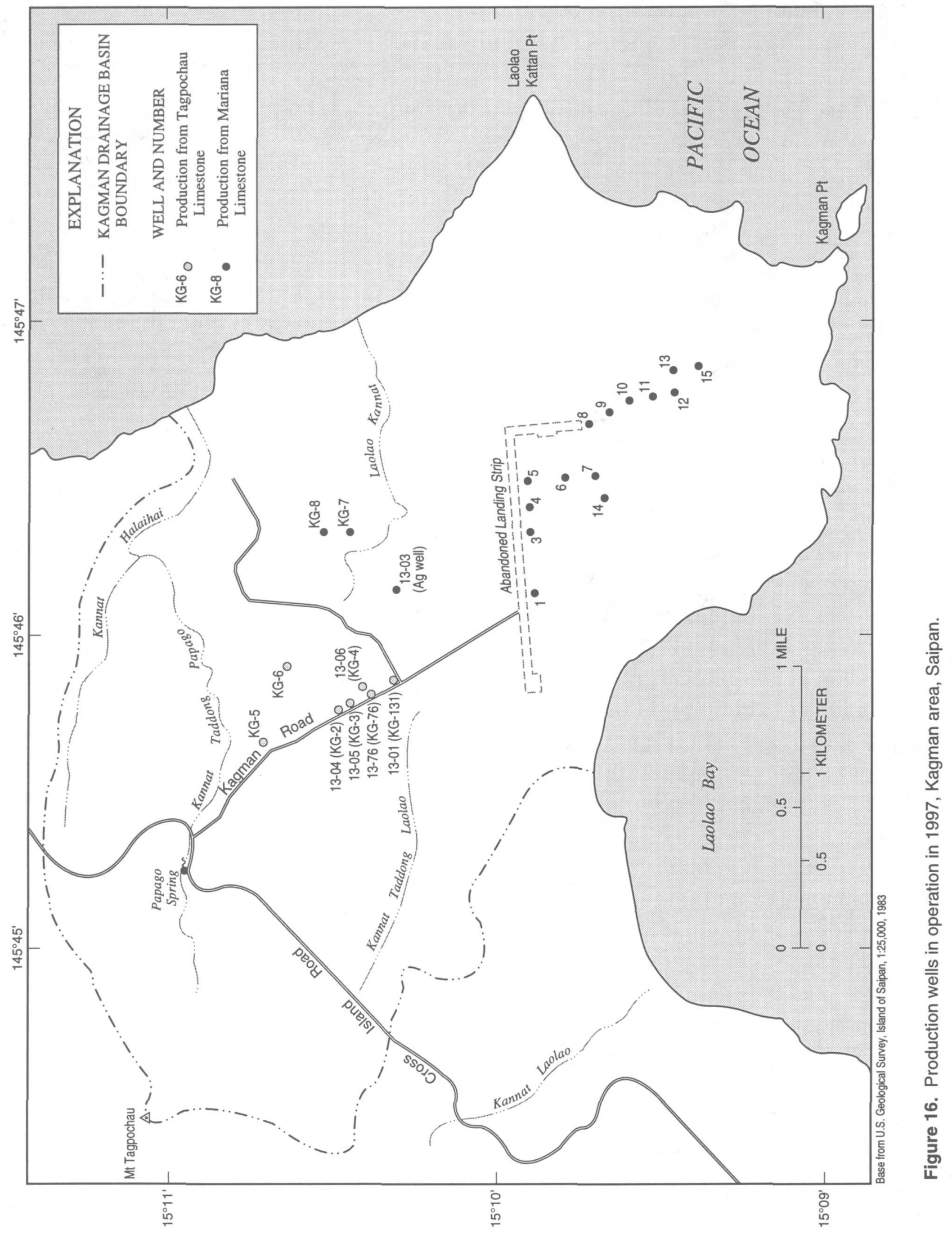


Table 2. Pumping rates and chloride-ion concentration for wells producing in the Kagman area, Saipan [gal/min, gallons per minute; $\mathrm{mg} / \mathrm{L}$, milligrams per liter]

\begin{tabular}{|c|c|c|c|c|c|c|}
\hline & Well name & Year drilled & $\begin{array}{c}1995 \text { average } \\
\text { pumping rate } \\
\text { (gal/min) }\end{array}$ & $\begin{array}{c}\text { Instantaneous } \\
\text { pumping rate } \\
\text { (gal/min) }\end{array}$ & $\begin{array}{c}\text { Chloride-ion } \\
\text { concentration } \\
\text { (mg/l) }\end{array}$ & Geologic formation \\
\hline & $13-76(\mathrm{KG}-76)$ & 1956 & 70 & 150 & 2,800 & Tagpochau Limestone \\
\hline & 13-03(Ag. well) & 1970 & $55^{\mathrm{c}}$ & 90 & $900^{d}$ & Mariana Limestone \\
\hline & 13-01 (KG-131) & 1981 & 150 & 200 & 710 & Tagpochau Limestone \\
\hline & $13-04(\mathrm{KG}-2)$ & 1987 & 30 & 55 & 120 & Tagpochau Limestone \\
\hline & $13-05$ (KG-3) & 1987 & 60 & 70 & 1,100 & Tagpochau Limestone \\
\hline & $13-06(\mathrm{KG}-4)$ & 1987 & 50 & 95 & $1,500^{\mathrm{e}}$ & Tagpochau Limestone \\
\hline & 1 (golf course) & 1991 & 25 & 45 & 800 & Mariana Limestone \\
\hline & 3 (golf course) & 1991 & 25 & 45 & 380 & Mariana Limestone \\
\hline & 4 (golf course) & 1991 & 25 & 45 & 350 & Mariana Limestone \\
\hline & 5 (golf course) & 1991 & 25 & 45 & 900 & Mariana Limestone \\
\hline & 6 (golf course) & 1991 & 25 & 45 & 1,500 & Mariana Limestone \\
\hline & 7 (golf course) & 1991 & 25 & 45 & 450 & Mariana Limestone \\
\hline & 8 (golf course) & 1991 & 25 & 45 & 350 & Mariana Limestone \\
\hline & 9 (golf course) & 1992 & 25 & 45 & 850 & Mariana Limestone \\
\hline & 10 (golf course) & 1992 & 25 & 45 & 900 & Mariana Limestone \\
\hline & 11 (golf course) & 1992 & 25 & 45 & 230 & Mariana Limestone \\
\hline & 12 (golf course) & 1992 & 25 & 45 & 440 & Mariana Limestone \\
\hline & 13 (golf course) & 1992 & 25 & 45 & 1,500 & Mariana Limestone \\
\hline & 14 (golf course) & 1992 & 25 & 45 & 430 & Mariana Limestone \\
\hline & KG-5 & 1992 & 15 & 20 & $300^{f}$ & Tagpochau Limestone \\
\hline & KG-6 & 1992 & 50 & 65 & 240 & Tagpochau Limestone \\
\hline & KG-7 & 1995 & $30^{g}$ & 35 & 300 & Mariana Limestone \\
\hline & KG-8 & 1995 & $30^{g}$ & 35 & 380 & Mariana Limestone \\
\hline & 15 (golf course) & 1996 & $25^{\mathrm{gh}}$ & 45 & 230 & Mariana Limestone \\
\hline & & Total ...... & 890 & 1,445 & \multicolumn{2}{|c|}{ (= 468 million gallons per year) } \\
\hline & \multicolumn{6}{|c|}{ Estimate based on pump size and/or peak season pumpage } \\
\hline 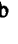 & \multicolumn{6}{|l|}{ April 1997} \\
\hline c & \multicolumn{6}{|l|}{1989} \\
\hline d & \multicolumn{6}{|l|}{ March 1989} \\
\hline \multicolumn{7}{|c|}{ April 1996} \\
\hline \multicolumn{7}{|c|}{ June 1995} \\
\hline \multicolumn{7}{|c|}{1996} \\
\hline & \multicolumn{6}{|c|}{ Data from Lau Lau Golf Course, oral commun., 1997} \\
\hline
\end{tabular}

pumping from individual wells ranged from 25 to 55 $\mathrm{gal} / \mathrm{min}$. The average pump rate of wells in the Mariana Limestone was about $27 \mathrm{gal} / \mathrm{min}$ per well. Total pumpage from all the wells was about $245 \mathrm{Mgal} / \mathrm{yr}(670,000$ $\mathrm{gal} / \mathrm{d}$ ). Fourteen of the wells were used to supply irrigation water to the golf course. Wells KG-7 and KG-8 contributed water to the public-supply system in the Kagman area. Water from well 13-03 (Ag. well) was used primarily for agriculture.
The estimated total pumpage in 1997 from the 24 production wells in the Kagman area was $468 \mathrm{Mgal} / \mathrm{yr}$ (about $1.3 \mathrm{Mgal} / \mathrm{d}$ ), which was about 7 to 10 percent of the estimated ground-water recharge. Within the ground-water system in the Kagman drainage basin, pumpage from the Tagpochau Limestone was concentrated in a small area whereas pumpage from the Mariana Limestone was spread over a wider area of the peninsula (fig. 16). 


\section{Chloride-Ion Concentrations}

When water is pumped from a freshwater lens, the lowering of ground-water levels associated with pumping will result in an upward movement of the underlying saltwater. Water samples have been collected intermittently from production wells in the Kagman area by the DEQ, the CUC Laboratory, and the USGS. Chlorideion concentrations over time from production wells in the Kagman area are given in table 3.

Of the 24 production wells in the Kagman area in 1997, nine were producing water with a chloride-ion concentration of $380 \mathrm{mg} / \mathrm{L}$ or less (wells KG-2, $-6,-7$, -8 , and golf course wells $3,4,8,11$, and 15) (tables 2 and 3). Seven of these wells yielded water from the Mariana Limestone (well KG-7, -8 , and golf course wells $3,4,8,11$, and 15) (table 3). The average chlorideion concentrations of water from all production wells in the Tagpochau and Mariana Limestones were about 1,100 and $600 \mathrm{mg} / \mathrm{L}$, respectively. The higher average chloride-ion concentration of water from wells in the Tagpochau Limestone may be a result of the closer spacing and higher average pumping rate compared with wells in the Mariana Limestone (table 3 and fig. 16). However, to thoroughly investigate the cause for the higher average chloride-ion concentration, more information is needed on water levels, pumping rates, hydraulic characteristics, and construction details of individual wells.

Water-level data from the test wells indicate that the thickness of the freshwater lens in the Mariana Limestone varies seasonally with rainfall. Less recharge during the dry season usually results in a decline in water-level altitude and a decrease in the depth to the 50-percent freshwater-saltwater interface. Chloride-ion concentration in well 13-03 (Ag. well) was measured intermittently from 1983 to 1989 and compared with rainfall in the Kagman area for the same time period (fig. 17). Figure 17 shows that periods of high rainfall generally correspond with low chlorideion concentration in well 13-03 (Ag. well).

The Tagpochau and Mariana Limestones make up a continuous aquifer system in the Kagman area. Pumping from wells in the Tagpochau Limestone may affect water levels and chloride-ion concentrations in both the Tagpochau and Mariana Limestones. Chloride-ion concentrations at well 13-03 (Ag. well), which was completed in the Mariana Limestone, began increasing in
1987 and 1988 following the start of pumping from nearby wells 13-04 (KG-2), 13-05 (KG-3), and 13-06 (KG-4), all of which are completed in the Tagpochau Limestone. Additionally, chloride-ion concentrations at wells 13-76 (KG-76) and 13-01 (KG-131) rose from potable to non-potable levels between 1987 and 1988 (table 3).

The average water level in observation well 13-78 declined between 1987 and 1989 (fig. 18). The decline was probably a result of a lowering of water levels in the Tagpochau Limestone caused by an increase in groundwater withdrawal at nearby wells 13-04 (KG-2), 13-05 (KG-3), and 13-06 (KG-4). The water level at observation well 13-78 declined from about $19 \mathrm{ft}$ in 1986 to as low as about $15 \mathrm{ft}$ in September 1988 (fig. 18). The water-level decline that began in 1987 may also be associated with the increase in chloride-ion concentrations beginning in 1987-88 (table 3).

The chloride-ion concentration of water withdrawn from wells in the permeable Mariana Limestone can vary with duration and rate of pumping. Several water samples were collected in 1989 from well 13-03 (Ag. well), which is pumped intermittently at 90 $\mathrm{gal} / \mathrm{min}$ for agricultural use. The first water sample, collected in mid-January 1989 after several weeks of nearcontinuous pumping, had a chloride-ion concentration of $780 \mathrm{mg} / \mathrm{L}$. The pump was then turned off for 5 days. The second water sample, collected within the first hour after the pump was turned back on, had a chloride-ion concentration of $350 \mathrm{mg} / \mathrm{L}$. After 25 hours of pumping the third water sample was collected and the chlorideion concentration had risen to $530 \mathrm{mg} / \mathrm{L}$. Other factors that may contribute to the rising chloride-ion concentration of water pumped from well 13-03 are the total depth of the well (about $20 \mathrm{ft}$ below sea level) and the pumping rate (about $90 \mathrm{gal} / \mathrm{min}$ in 1989). A lower pumping rate may allow a continuous production of water with less than 2 percent seawater chloride-ion concentration.

\section{HYDRAULIC CHARACTERISTICS OF THE MARIANA LIMESTONE}

The hydraulic characteristics of the Mariana Limestone were determined from analysis of aquifer tests done at five test wells (13-T1b, 13-T3 to 13-T6). An aquifer test was also done at test well 13-T2b, which was completed in the Donni Sandstone. Aquifer tests 


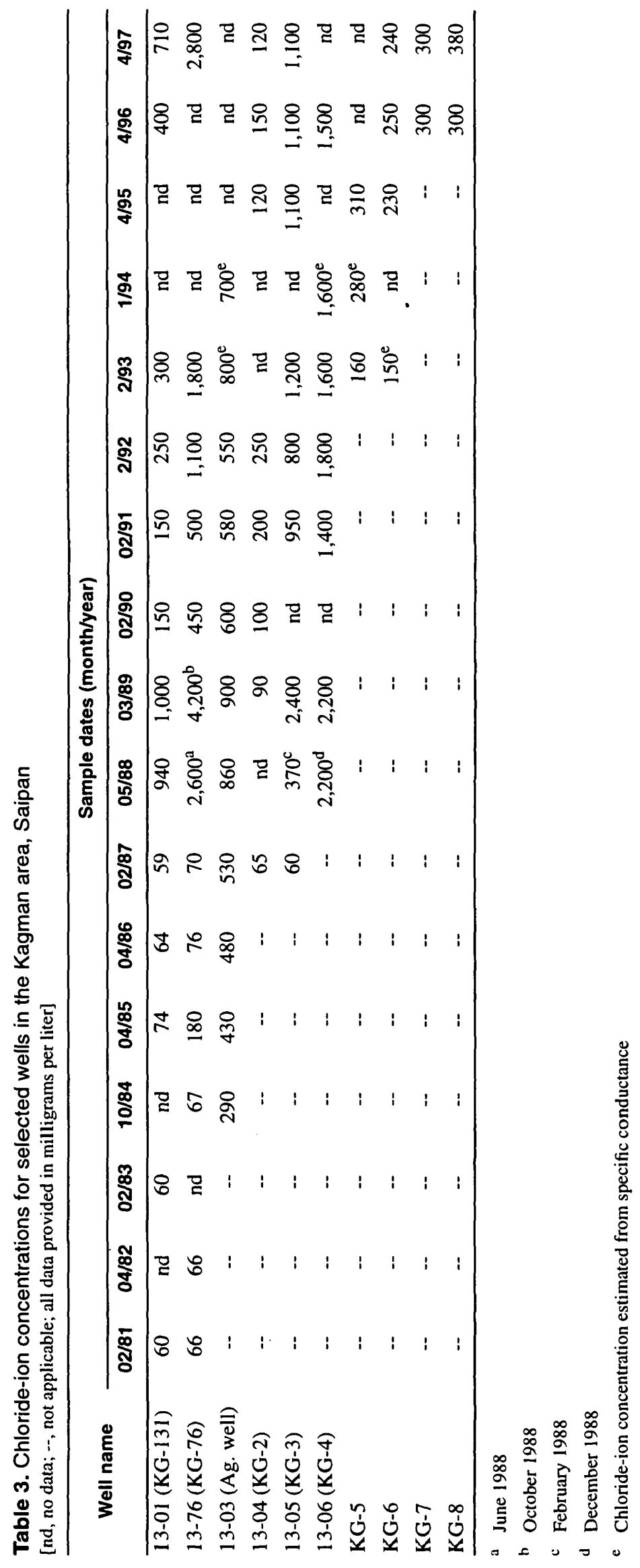



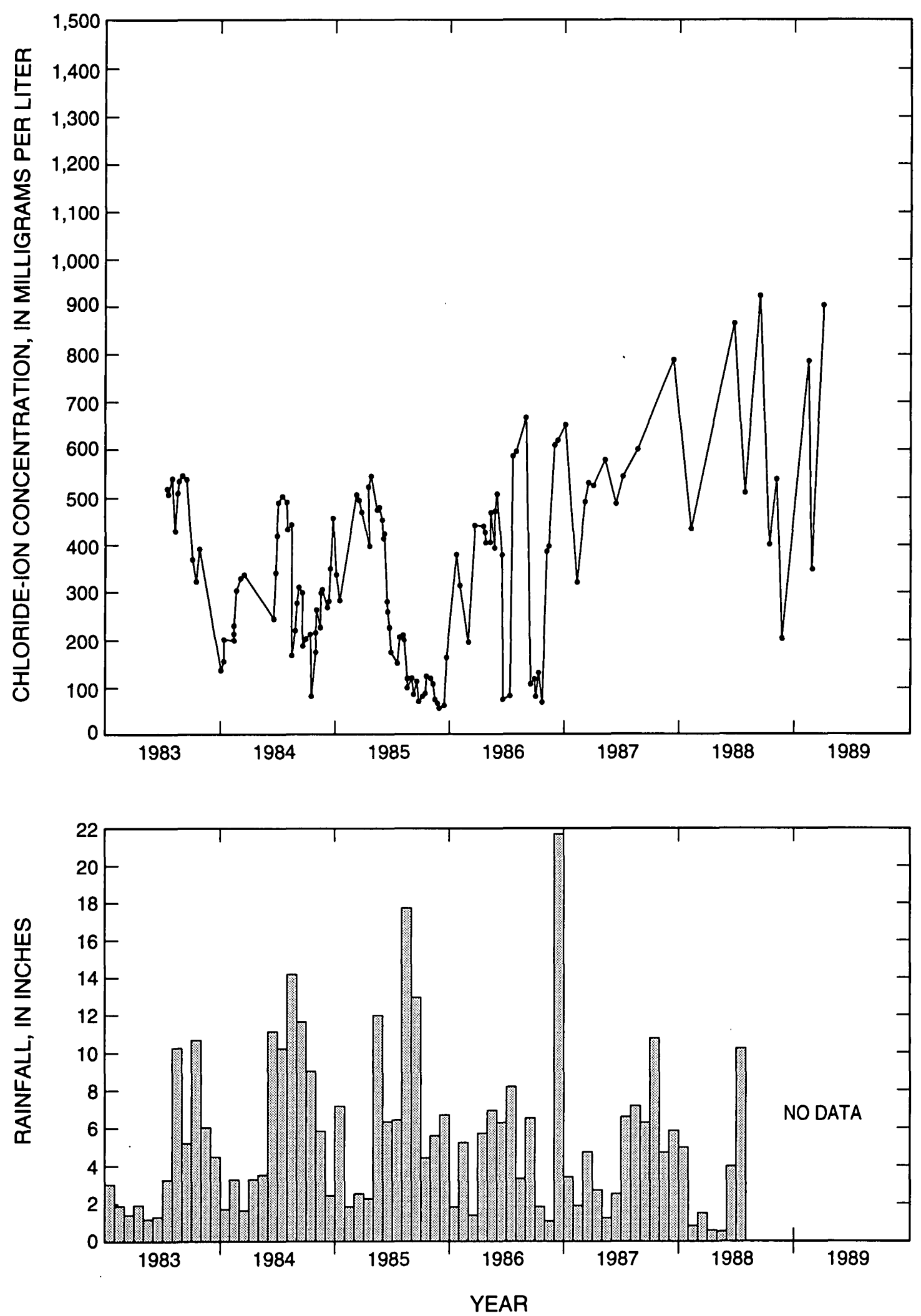

Figure 17. Chloride-ion concentration for well 13-03 (Ag. well) and rainfall, Kagman area, Saipan. 


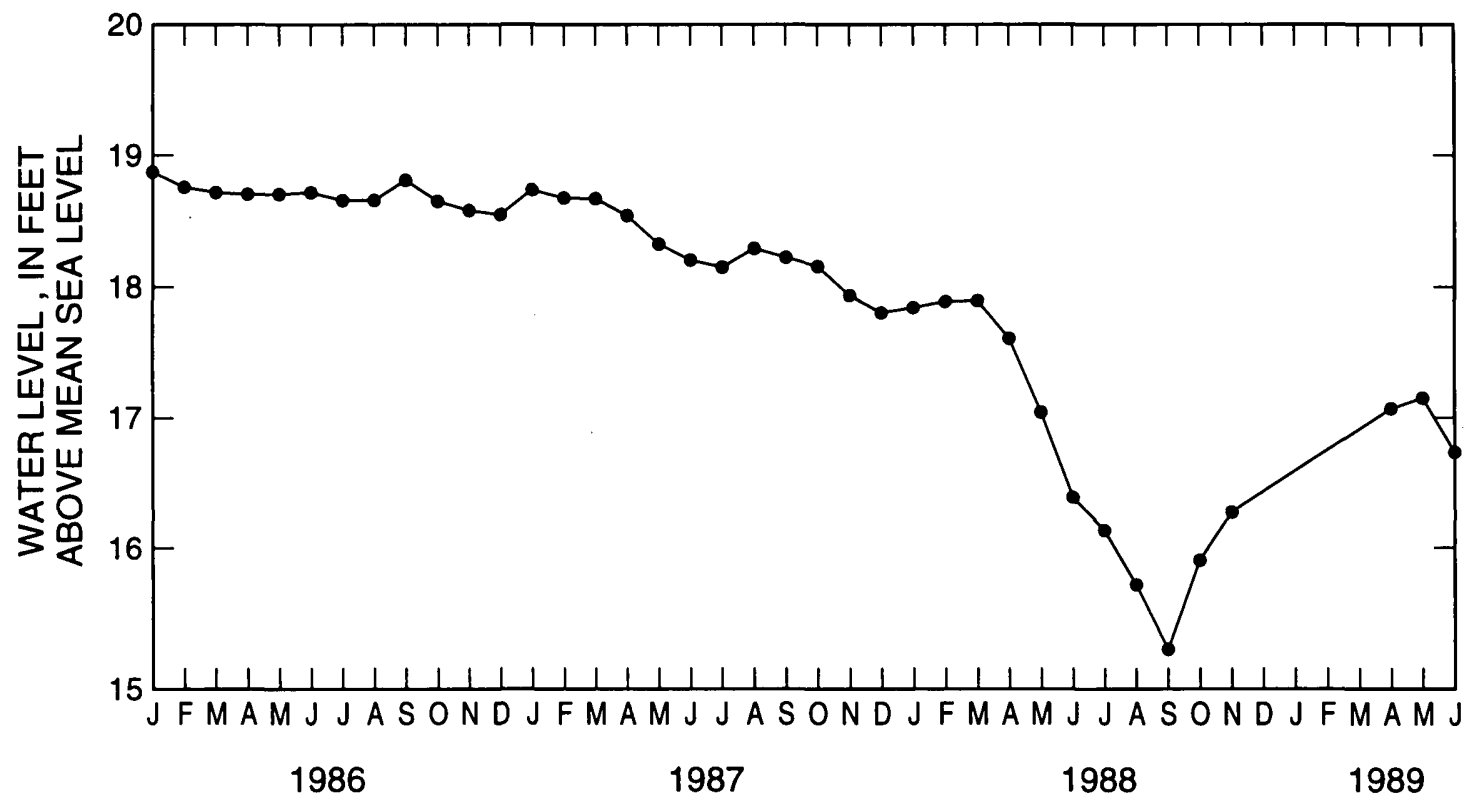

Figure 18. Water level in observation well 13-78 (KG-76) from January 1986 through June 1989 , Kagman area, Saipan.

consisted of pumping each well and recording drawdown in the pumping well over a 25 -hour period, except at test well 13-T1b. Test well 13-T1b, about $50 \mathrm{ft}$ from well 13-03, was drilled so that it penetrated the same part of the aquifer as well 13-03. Well 13-03 was pumped for a 25 -hour period and depth to water was measured in both wells during the test.

Before pumping, all the test wells were cleaned and developed with air, and background water-level data were collected for several days preceding the test. Analysis of the data required corrections for tidal and barometric effects in the observed drawdown. This was done by the techniques described by Hsieh and others (1987).

Aquifer-test data from all the test wells completed in the Mariana Limestone were analyzed using the methods of Boulton (1963) and Neuman (1975). The Boulton method accounts for the effects of delayed yield to a fully penetrating pumping well and the Neuman method also corrects for the effects of partial penetration and vertical anisotropy. The observed response from all of the test wells fit delayed-yield curves. The delayed-yield response was considered reasonable given an unconfined aquifer, the presence of clay stringers in the limestone, and the possibility of water moving vertically through fracture and solution features. The
Neuman method was preferred because the test wells do not fully penetrate the aquifer. Aquifer penetration ranged from 23 to 80 percent (assuming the bottom of the aquifer to be the line of 50-percent seawater chloride-ion concentration) (table 4). The effect of partial penetration on observed drawdown, and therefore the test results, may be large for wells that penetrate only a small portion of the aquifer (such as test wells 13-T4 and 13-T6). Values of transmissivity obtained from the two analytical techniques were converted to hydraulic conductivity and are listed in table 4 . Storage coefficient was calculated from the data obtained from 13T1b (table 4).

Results from the Neuman method consistently gave values for transmissivity and hydraulic conductivity larger than the values obtained from using the Boulton method (table 4). The difference is expected because the Boulton method assumes a fully penetrating well, whereas the Neuman method corrects for the effects of partial penetration. The largest proportional difference for transmissivity and hydraulic conductivity computed by the two methods for the Mariana Limestone was obtained from analysis of data from test wells 13-T4 and 13-T6, which penetrated only about one quarter of the aquifer. Values computed for hydraulic conductivity and storage coefficient at $13-\mathrm{T} 1 \mathrm{~b}$ using the 


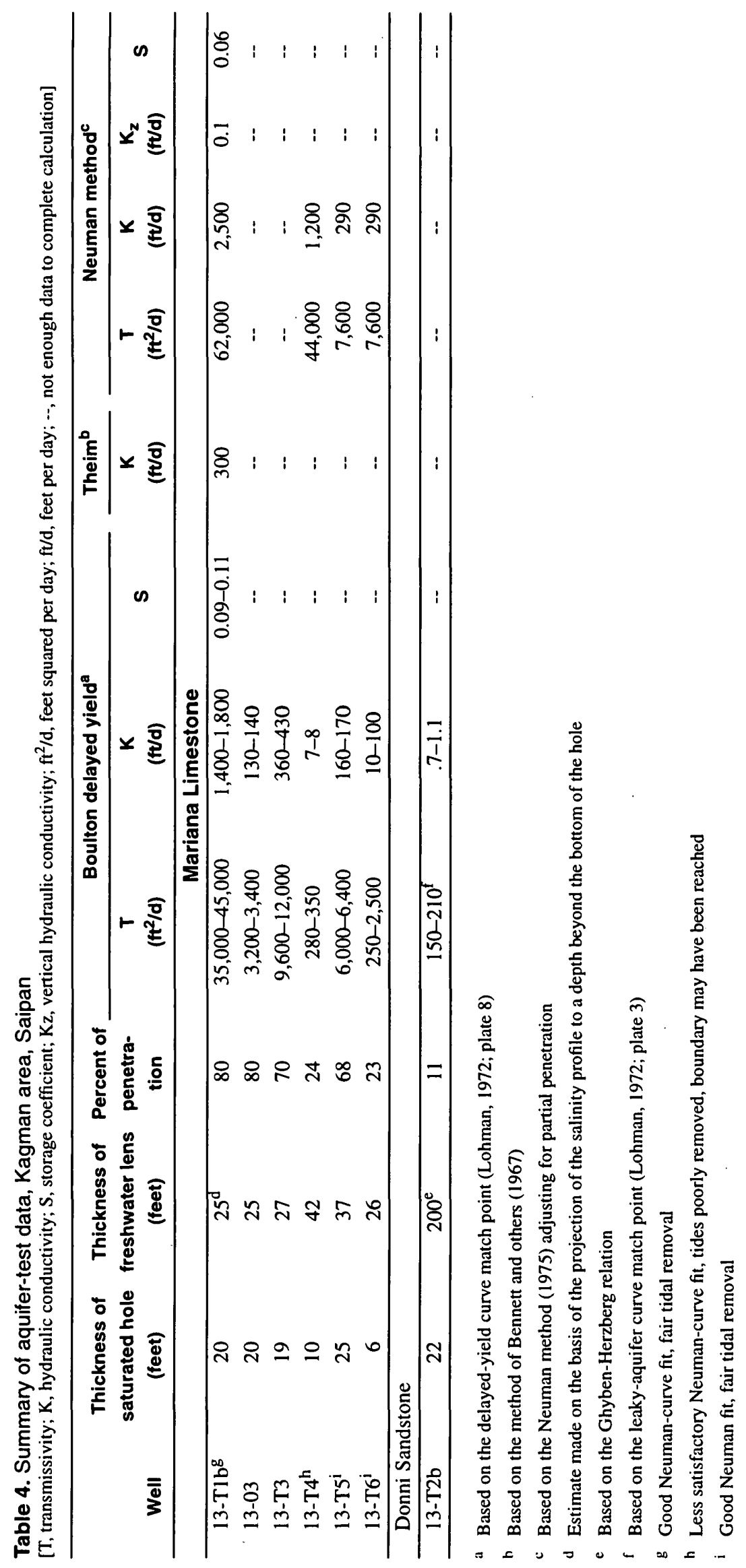


Boulton and Neuman methods were similar (table 4). Well 13-T1b penetrates about 80 percent of the aquifer so the effect of partial penetration on the analysis is considerably less than for test wells 13-T4 and 13-T6. The values for transmissivity obtained from the Neuman method are considered more reliable than those obtained using the delayed-yield curves because the Neuman method corrects for partial penetration.

The calculated values for hydraulic characteristics may be low for most of the tests because drawdown was measured in the pumped well where drawdown is higher than in the adjacent rock as a result of well inefficiency. Test well 13-T1b was not pumped during the aquifer tests; therefore, transmissivity, hydraulic conductivity, and storage coefficient derived from the Boulton and Neuman methods are unaffected by well inefficiency. Drawdowns measured at well 13-03 and 13-T1 $\mathrm{b}$ also were analyzed by the method described by Bennett and others (1967). The hydraulic conductivity estimated from the method of Bennett and others (1967) may be affected by well inefficiency in well 13-03; thus, the value of $300 \mathrm{ft} / \mathrm{d}$ estimated by this method may be lower than the actual value.

Assuming drawdowns in test wells 13-T5 and 13T6 were not significantly affected by well inefficiency, transmissivities calculated using the Neuman method are considered accurate because the removal of tidal influences from drawdown was considered reliable and a good fit with the Neuman curve was obtained. Calculated transmissivity and hydraulic conductivity are regarded as rough estimates of actual values at well 13T4 because of the inability to satisfactorily remove tidal effects and a poor match with the Neuman curves.

Results of the Neuman analysis of the aquifer tests indicate that the hydraulic conductivity of the Mariana Limestone ranged from $290 \mathrm{ft} / \mathrm{d}$ to $2,500 \mathrm{ft} / \mathrm{d}$ at wells where tidal influences were reliably removed and the data fit the Neuman curve closely (table 4). Storage coefficient, obtained from two different analyses at the same location (13-T1b) is about 0.06 to 0.11 . The vertical hydraulic conductivity, calculated from data collected at $13-\mathrm{T} 1 \mathrm{~b}$, is $0.1 \mathrm{ft} / \mathrm{d}$.

The aquifer test done at test well $13-\mathrm{T} 2 \mathrm{~b}$ provides an estimate of the transmissivity and hydraulic conductivity of the Donni Sandstone and the overlying rock, which consisted of thick clay with occasional stringers of limestone. The value for hydraulic conductivity estimated during the test, 0.7 to $7 \mathrm{ft} / \mathrm{d}$, is one to two orders of magnitude less than values determined for the Mariana Limestone.

\section{ESTIMATED WELL YIELDS}

The objectives of this study included examining the feasibility of developing fresh ground water from the Mariana Limestone. Results of this study indicate that a freshwater lens is present in the Mariana Limestone, but that the limited thickness of the lens restricts pumping rates at any given location. The yield of freshwater from wells in the Kagman area is highly dependent on well depth relative to sea level, water level, depth to the transition zone, transmissivity, and the proximity of the well to the ocean. In general, maximum production can be obtained from widely spaced wells pumping at low rates. For the purpose of this study, the actual rate of production that might be obtainable from a single well is of concern. As a result, the following estimate of potential pumping rates is based on historical pumping information, chloride-ion concentrations, and on the results of this study.

Test wells were pumped at rates ranging from 9 $\mathrm{gal} / \mathrm{min}$ at test well $13-\mathrm{T} 4$ to $76 \mathrm{gal} / \mathrm{min}$ at well $13-\mathrm{T} 5$. Well 13-03 (Ag. well), which was used for testing at 13$\mathrm{T} 1 \mathrm{~b}$, was pumped at $90 \mathrm{gal} / \mathrm{min}$. The rate at which each was pumped and the chloride-ion concentrations measured in each at the end of the test are given in table 5 . The depth of each test well below the water table and the depth below the water table of the 2-and 50-percent interfaces (fig. 6) are listed in table 5. Chloride-ion concentrations over time for each well are shown in figure 19. The only test wells in the Mariana Limestone with chloride-ion concentrations below $500 \mathrm{mg} / \mathrm{L}$ at the end of the 25-hour test were test wells 13-T4 and 13-T6. Test well $13-\mathrm{T} 4$ was pumped at only $9 \mathrm{gal} / \mathrm{min}$, the lowest pumping rate used, and well 13-T6 was pumped at $18 \mathrm{gal} / \mathrm{min}$. Pumping rates at all of the other locations where tests were done ranged from 40 to $90 \mathrm{gal} / \mathrm{min}$. Test wells 13-T4 and 13-T6 penetrated only 10 and $6 \mathrm{ft}$ below the water table, respectively, and all other test wells penetrated more than $10 \mathrm{ft}$ below the water table (table 5). Total depth of test well 13-T4 was reduced by backfilling before the test because of high chloride-ion concentrations at $34 \mathrm{ft}$ below the water table.

Test results indicate that yields of about $70 \mathrm{gal} / \mathrm{min}$ or more probably will not be possible from a single well in the Mariana Limestone if chloride-ion concentrations 


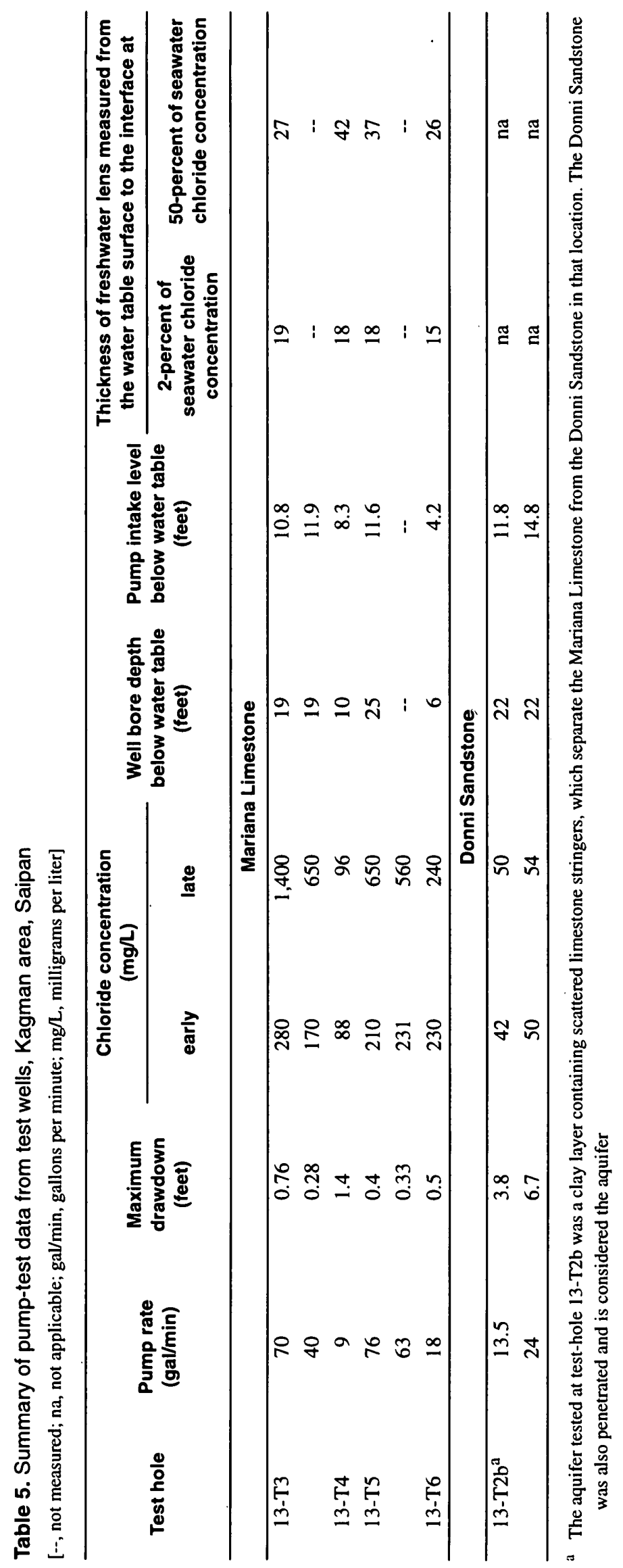




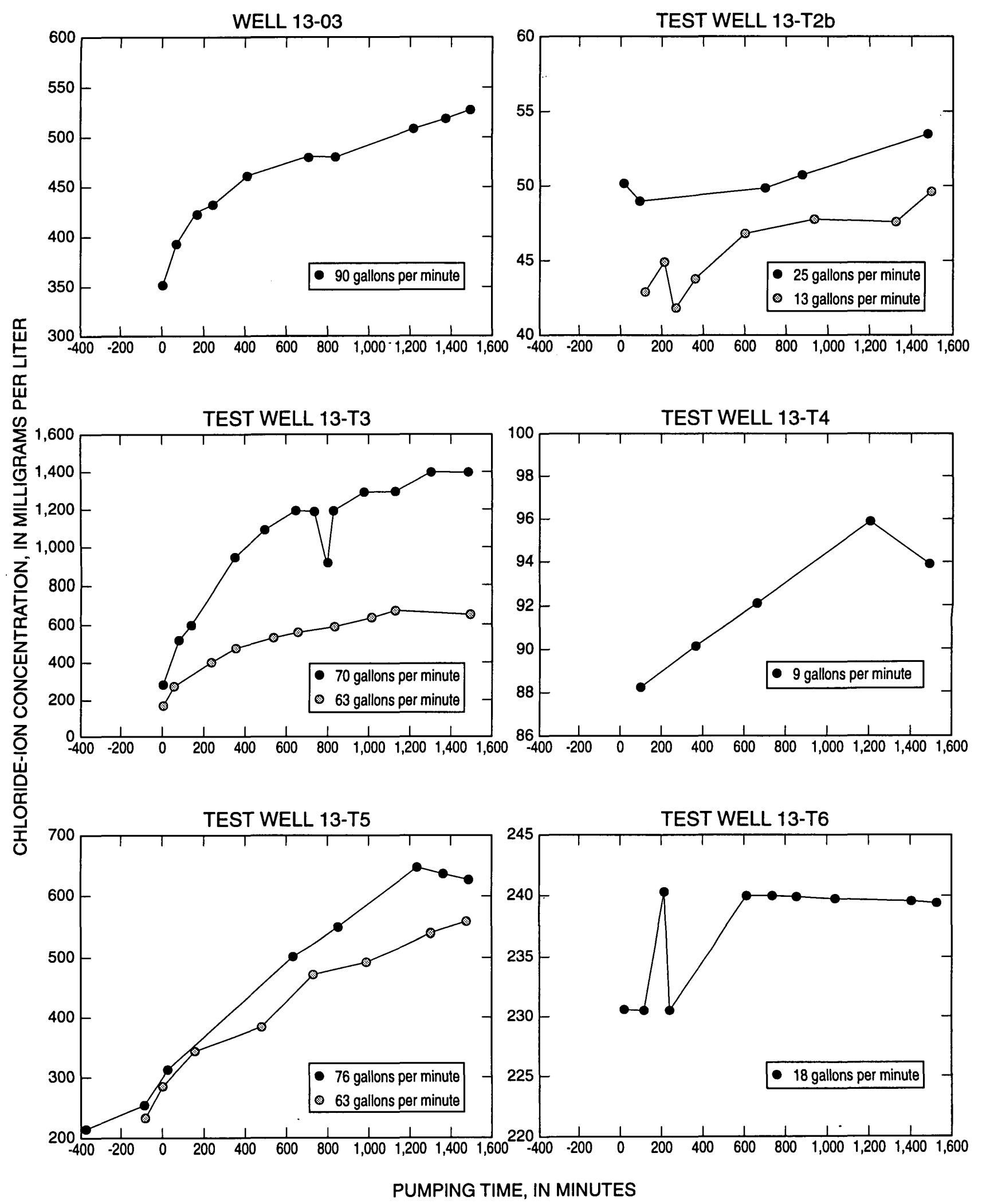

Figure 19. Chloride-ion concentrations during pump tests (January 20-21, 1989) at selected production wells and test wells, Kagman area, Saipan. 
are to remain below $500 \mathrm{mg} / \mathrm{L}$. The short-term test pumping indicates the yields of $20 \mathrm{gal} / \mathrm{min}$ or less may be possible, but extrapolation of the results from these tests to reach conclusions on long-term well yield is tenuous. Test wells that penetrated more than about 25-percent of the freshwater-lens thickness did not produce water with less than $500 \mathrm{mg} / \mathrm{L}$ chloride-ion concentration at the end of the 25-hour pumping period (tables 4 and 5).

As the water level declines in a well because of pumping, the 50-percent freshwater-saltwater interface will move upward in response to the lower freshwater head and because of dispersion induced by the upward movement of water to the well. In addition, the reduction of freshwater outflow to the sea by the amount pumped from the well may cause the interface to move inland. The increase in chloride-ion concentrations with pumping time shown in figure 19 may be a result of such processes. A well that is pumped for short periods of time may not exceed acceptable chloride-ion concentrations, but the chloride-ion concentration may increase if the well is pumped at the same rate for longer periods of time.

McWhorter and Sunada (1977) state that "As a practical matter, the interface (as a result of upconing) is apparently stable for upconed heights less than or equal to about one-third of the distance between the bottom of the well and the original interface elevation (Dagan and Bear, 1968)." To preclude unacceptable chloride-ion concentrations as a result of upconing (fig. $20)$, the long-term drawdown $(s)$ in a well must be restricted to:

$$
s=\left(\Delta \rho / \rho_{f}\right)(b-l) / 3
$$

where:

$\Delta \rho$ is $\rho_{s}-\rho_{f}$.

$\rho_{f}$ is density of freshwater,

$\rho_{s}$ is density of saltwater,

$b$ is distance from the undisturbed water table to the original interface, and

$l$ is distance from the undisturbed water table to the bottom of well.

McWhorter and Sunada (1977) used this relation to obtain an equation expressing maximum discharge from the well as a function of $l, b, K$, and $r_{e} / r_{w}$ such that:

$$
Q_{m}=\frac{\pi K b^{2}}{\ln \left(r_{e} / r_{w}\right)}\left\{\frac{\Delta \rho}{\rho_{f}}\left(\frac{1-\frac{l}{b}}{3}\right)\left[2-\left(1+\frac{\Delta \rho}{\rho_{f}}\right) \frac{\Delta \rho}{\rho_{f}}\left(\frac{1-\frac{l}{b}}{3}\right)\right]\right\}
$$

where:

$K$ is hydraulic conductivity of the aquifer,

$r_{e}$ is radial extent of the cone of depression,

$r_{w}$ is radius of the well,

$Q_{m}$ is maximum pumpage, and

$\Delta \rho$ is density of saltwater minus density of freshwater $\left(\rho_{s}-\rho_{f}\right)$.

If the screened part of the well is small compared with the depth of the well, this reduces to:

$$
Q_{m}=\frac{2 \pi}{3}(b-l) \frac{2 \Delta \rho}{\rho_{f}} K
$$

where:

$l$ is the distance between the undisturbed water table and the well screen. 


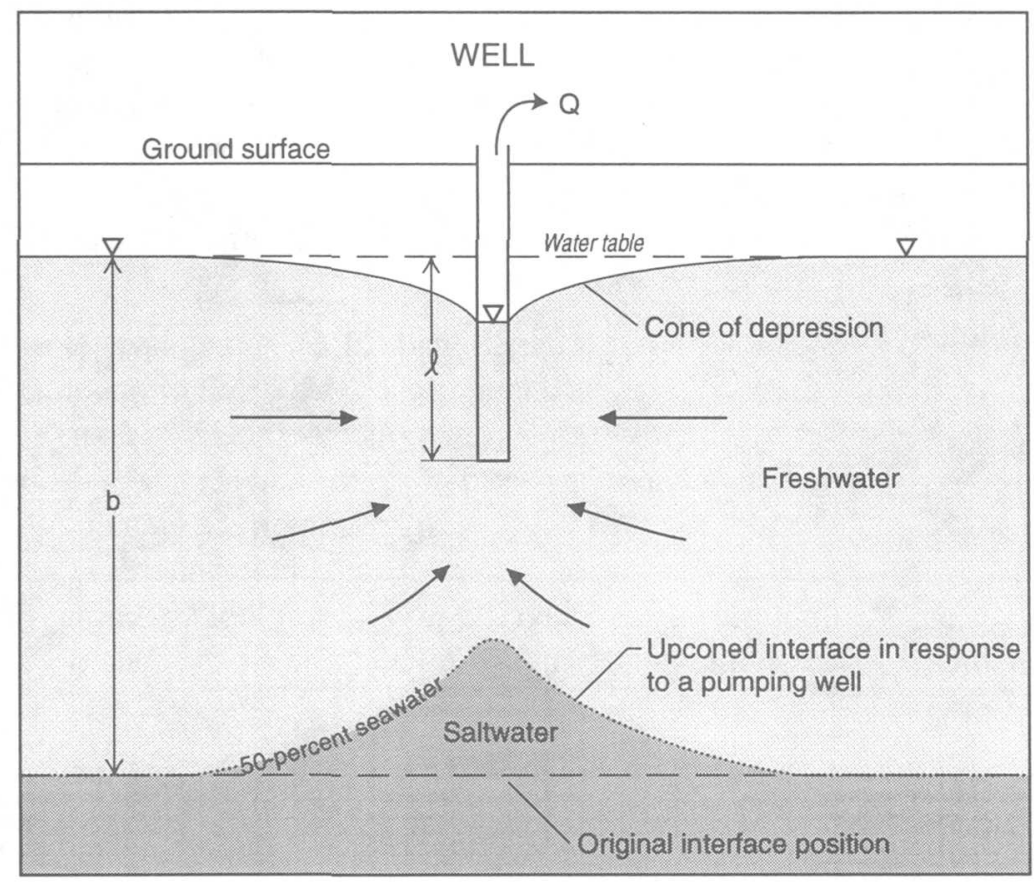

\section{EXPLANATION}

b

l

Q

$\nabla$
DISTANCE FROM WATER-TABLE SURFACE TO ORIGINAL INTERFACE

DISTANCE FROM WATER-TABLE TO BOTTOM OF WELL

PUMPING RATE OF WELL

WATER TABLE

Figure 20. Upconing of the freshwater-saltwater interface beneath a pumping well (modified from McWhorter and Sunada, 1977).

From equations 2 and 3 , it is apparent that the smaller the depth of penetration of the well below the water table, the greater the predicted yield without inducing unacceptable chloride-ion concentrations. The distance from the water table to the bottom of the well ( $l$ ) needs to be greater than the combined length of the submersible pump and motor plus the seasonal and tidal fluctuations in water level and the maximum expected drawdown in the well. The seasonal range in water levels is less than $1 \mathrm{ft}$. The maximum drawdown recorded in test wells drilled into the Mariana Limestone during the aquifer testing was less than $1 \mathrm{ft}$ for discharges up to $90 \mathrm{gal} / \mathrm{min}$. Assuming values for $l$ equal to 8 and $10 \mathrm{ft}$, then values for maximum pumpage $\left(Q_{m}\right)$ can be calculated from equations 2 or 3 , as appropriate. A conservative estimate would use the lowest value for $K(290 \mathrm{ft} / \mathrm{d})$ obtained from the Neuman method, the lowest head value for the study area (about $1.8 \mathrm{ft}$ ), and the ratio of 15 to 1 for the depth to the 50-percent freshwater-saltwater interface based on the freshwater head. Using these values in equation 3 , a maximum pumping rate is estimated as about $20 \mathrm{gal} / \mathrm{min}$ for an $l$ of $10 \mathrm{ft}$ and 30 $\mathrm{gal} / \mathrm{min}$ for an $l$ of $8 \mathrm{ft}$. These equations assume a density of $1.025 \mathrm{~g} / \mathrm{cm}^{3}$ for saltwater and $1.0 \mathrm{~g} / \mathrm{cm}^{3}$ for freshwater.
The above calculation assumes that the well is pumped continuously throughout the year. The analysis also assumes that the aquifer is homogenous and isotropic, which probably is not a valid assumption. If the vertical hydraulic conductivity of the limestone is small compared with the horizontal conductivity, the anisotropy would cause pumpage-induced water-level declines to be less at the bottom of the limestone than at the water table. Therefore, anisotropy in the aquifer may lessen the effects of upconing from that predicted by equation 2 . Solution channels, however, could conceivably provide horizontal and vertical pathways for seawater intrusion, which is not accounted for in the analysis.

Field testing of the analytical results indicate that freshwater can be obtained from individual wells at pumping rates of about 20 to $30 \mathrm{gal} / \mathrm{min}$ if well depth does not exceed $8 \mathrm{ft}$ below sea level and there is minimal interference from pumping at other wells. Two municipal production wells, KG-7 and KG-8, presently (1997) are producing freshwater at about $30 \mathrm{gal} / \mathrm{min}$ (fig. 15). These wells, completed in 1995, were drilled to about $6 \mathrm{ft}$ below mean sea level in the Mariana Limestone and are separated by about $800 \mathrm{ft}$. 
The data indicate that freshwater can be obtained from wells constructed in the Mariana Limestone but long-term pumping rates need to be low. To obtain freshwater from the thin zone above the underlying saltwater, wells need to induce minimal drawdown to prevent saltwater upconing. When the probable yield from an individual well is compared to the projected increased water demand, it is apparent that many widely spaced wells pumping at low rates will be needed.

\section{SUMMARY AND CONCLUSIONS}

The feasibility of obtaining freshwater from the Mariana Limestone in the Kagman area was investigated by drilling test wells to obtain information on the geology, water levels, water quality, and hydraulic characteristics of the limestone aquifer. Results of the study indicate that additional ground-water withdrawal is feasible from the Mariana Limestone, but that pumping rates, depth, and spacing of individual wells are important if water is desired with a chloride-ion concentration less than 2-percent that of seawater.

Three geologic formations crop out in the Kagman drainage basin. The Mariana Limestone of Pleistocene age is the youngest formation and is the major waterbearing unit in the Kagman area. The Mariana Limestone is white to grey fossiliferous limestone that is moderately to cavernously porous below the water surface. The hydraulic conductivity of the Mariana Limestone, estimated from data collected at the test wells, ranges from 290 to 2,500 ft/d using the Neuman method. Calculated transmissivity values for the Mariana Limestone range from 7,600 to $62,000 \mathrm{ft}^{2} / \mathrm{d}$. The storage coefficient of the limestone, determined at one test well location, is about 0.1 .

The Donni sandstone, a member of the Tagpochau Limestone, underlies the Mariana Limestone and constitutes a confining unit in the Kagman area. The hydraulic conductivity of the Donni Sandstone, calculated from data collected at test well 13-T2b, is about 1 to $7 \mathrm{ft} / \mathrm{d}$. The Tagpochau Limestone, of Miocene to Pliocene age, includes clastic sedimentary rocks of volcanic origin and impure to pure, white to pink carbonate rocks. Water in the Tagpochau Limestone constitutes the lower part of the aquifer system in the peninsula. The Densinyama Formation is the oldest formation in the Kagman drainage basin and consists of volcanically derived breccias, conglomerates, and sandstones of Eocene age.

The ground-water system in the Kagman drainage basin is recharged by rainfall infiltration. Rates of recharge to the aquifer system are about 13 to $18 \mathrm{Mgal} / \mathrm{d}$ depending on the evapotranspiration values used. Most recharge occurs during the wet season from July through November; thus, the rate of 13 to $18 \mathrm{Mgal} / \mathrm{d}$ represents seasonal recharge averaged for the year rather than the actual rate. Most of the recharge, about 9 to $12 \mathrm{Mgal} / \mathrm{d}$, is believed to enter the Mariana Limestone, and nearly all the remaining water is believed to enter the Tagpochau Limestone.

The freshwater lens in the Mariana Limestone is thin, about 15 to $21 \mathrm{ft}$, and is underlain by saltier water. The altitude of the water table is about 1.5 to $2.5 \mathrm{ft}$ and varies seasonally with rainfall. The Mariana Limestone generally has a high permeability; however, the thinness of the freshwater lens limits the availability of water from this aquifer. Analytical estimates of longterm pumping rates from a single well are about 30 $\mathrm{gal} / \mathrm{min}$ for a well which penetrates $8 \mathrm{ft}$ below the water table, and about $20 \mathrm{gal} / \mathrm{min}$ for a well which penetrates to $10 \mathrm{ft}$ below the water table.

Field testing of wells drilled during this project indicate that, at some wells, yields of about 20 to 30 $\mathrm{gal} / \mathrm{min}$ of freshwater probably are possible if pumping in other wells causes no interference. Two municipal production wells, drilled to $6 \mathrm{ft}$ below mean sea level in the Mariana Limestone, were producing freshwater at about $30 \mathrm{gal} / \mathrm{min}$ in 1997 . These rates of pumping assume that only freshwater ( 2 percent of seawater chloride-ion concentration or less) is desired. Ultimately, pumping rates will depend on the chloride-ion concentration that is acceptable.

\section{REFERENCES CITED}

Ayers, J.F., 1981, Evaluation of the groundwater resources of the Agag Basin, Saipan: University of Guam, Technical Report No. 31, 82 p.

Bennett, G.D., Ata-ur-Rehman, Sheikh, I.A., and Ali, Sabir, 1967, Analysis of aquifer tests in the Punjab region of West Pakistan: U.S. Geological Survey Water-Supply Paper 1608-G, p. G1-G56.

Boulton, N.S., 1963, Analyses of data from non-equilibrium pumping later allowing for delayed yield from storage: 
Instrument of Civil Engineering Proceedings, London, v. 26 , p. $469-482$.

Cloud, P.E., Schmidt, R.G., and Burke, H.W., 1956, Geology of Saipan, Mariana Islands: Part 1. General geology: U.S. Geological Survey Professional Paper 280-A, $126 \mathrm{p}$.

Cox, D.C., and Evan, T.R., 1956, Water supply, in Utilities study for island of Saipan: Honolulu, Hawaii, Belt, Lemmon and Lo, section IV, p. 41-86.

Dagan, G., and Bear, J., 1968, Solving the problem of local interface upconing in a coastal aquifer by the method of small perturbations: Journal of Hydraulic Research, v. 6 , no. 1 , p. $15-44$.

Davis, T., Jr., 1973, Saipan island water plan: District Administrator Mariana District, Trust Territory of the Pacific Islands, $113 \mathrm{p}$.

Hsieh, P.A., Bredehoeft, J.D., Farr, J.M., 1987, Determination of aquifer transmissivity from earth tides analysis: Water Resources Research, v. 23, no. 10, p. 1824-1832.

Hunt, C.D., Jr., 1997, Influence of atmospherically forced sea-level fluctuations on coastal ground-water levels at daily to interannual time scales (abs.): Abstracts with Program, Geological Society of America 1997 Cordilleran Section Meeting, Kailua-Kona, Hawaii, May 21-23, 1997 , v. 29, no. 5 , p. 20.
Lohman, S.W., 1972, Ground-water hydraulics: U.S. Geological Survey Professional Paper 708, 70 p.

M \& E Pacific, 1978, Water management plan for Saipan, Rota and Tinian: Department of Public Works, Commonwealth of the Northern Marianas, variously paged.

McWhorter, D.B., and Sunada, D.K., 1977, Ground-water hydrology and hydraulics: Fort Collins, Colo., Water Resources Publications, $163 \mathrm{p}$.

Mink, J.F., 1987, Hydrological characterization of the ground-water resources, island of Saipan: Report to the Division of Environmental Quality, Department of Public Health and Environmental Services, Commonwealth of the Northern Mariana Islands, $59 \mathrm{p}$.

Neuman, S.P., 1975, Analysis of pumping test data from anisotropic unconfined aquifers considering delayed yield: Water Resources Research, v. 11, no. 2, p. 329342.

Todd, D.K., 1980, Groundwater Hydrology: New York, John Wiley \& Sons, $535 \mathrm{p}$.

Van der Brug, Otto, 1985, Compilation of water resources development and hydrologic data of Saipan, Mariana Islands: U.S. Geological Survey Water-Resources Investigations Report 84-4121, 578 p. 


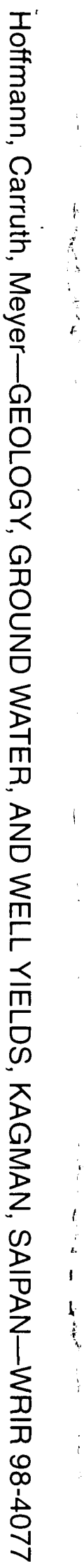

